\title{
Influencia de las propiedades de la fábrica de la catedral de León en su comportamiento estructural
}

\section{The influence of the masonry mechanical properties in the structural behaviour of the Leon's cathedral}

\author{
M. J. Casati Calzada(*), J. C. Gálvez Ruiz(**)
}

Recepción/Received: 03-VII-07

Aceptación/Accepted: 28-IV-08

Publicado online/Online publishing: 19-V-09

\section{RESUMEN}

Las propiedades de un material como la fábrica influyen de forma determinante en el comportamiento de la estructura. En una estructura histórica, como la catedral de León, se añade la incertidumbre del estado real del material y la composición de sus elementos estructurales. Estos aspectos dificultan la evaluación de la capacidad resistente de la estructura y la incidencia de actuaciones de reparación o remodelación. Este trabajo presenta el estudio realizado para seleccionar, mediante un análisis de sensibilidad del comportamiento de la estructura, cuáles son las variables del material que más afectan al comportamiento estructural de la catedral.

El estudio se inicia con el análisis estructural de la sección tipo para identificar las zonas de mayor responsabilidad. A continuación se hace el estudio estructural con la combinación de todas las variables, especialmente las dependientes de los materiales, modificando su valor. Mediante un tratamiento estadístico de los resultados, se determina qué parámetros de los adoptados afectan más al comportamiento de la estructura de fábrica y se establecen las conclusiones.

Palabras clave: fábrica, propiedades mecánicas, construcciones históricas, restauración, construcciones góticas.
SUMMARY

Mechanical and physical properties of the masonry have a considerable bearing on the structural behaviour. Ancient buildings, like Leon's cathedral, show uncertainty about real condition of the material and even structural compounds. These uncertainties make it difficult to assessment the bearing capacity of the structure and the affect of the restorations. This paper shows a study to select the most influential material's parameters on the structural behaviour. The study is based on a sensitiveness analysis.

The study starts with a structural analysis to select the most responsible areas of the transversal structural section. Then, the structural calculation is done by modifying the value of the material's parameters in the expected scatter band. The statistical study provides the most influential parameters on the structural masonry behaviour. Finally the conclusions are proponed.

Keywords: masonry, properties, ancient buildings, restorations, gothic buildings.

\footnotetext{
(*) Universidad Politécnica de Madrid, EUIT Aeronáutica (Madrid, España).

(**) Universidad Politécnica de Madrid, ETS. Ingenieros de Caminos, Canales y Puertos (Madrid, España).
} 


\section{INTRODUCCIÓN}

La adecuada conservación de las catedrales góticas constituye un importante reto que requiere el auxilio de muy diferentes disciplinas, que van desde la investigación histórica (documentos sobre cómo se construyó y qué modificaciones y actuaciones ha sufrido a lo largo de su historia) hasta la aplicación de modernas técnicas de conservación de los materiales. Junto a las actuaciones urgentes, el plan de conservación debe anticiparse a los problemas que puedan surgir, como el daño acumulado y la fatiga por efecto del tráfico, el deterioro del material debido a la contaminación ambiental o los asientos diferenciales en la cimentación originados por obras cercanas o vibraciones, entre otras posibles causas de deterioro. Una estructura histórica que ha permanecido en pie durante siglos puede sufrir un grave deterioro, e incluso colapsar, si estos aspectos no se han previsto, como desgraciadamente ha mostrado la historia. Por ello el análisis estructural y la evaluación de la seguridad estructural son con frecuencia contemplados dentro del Plan Director de una catedral.

El análisis estructural permite identificar los mecanismos resistentes del edificio, predecir el comportamiento ante las solicitaciones actuantes (incluidas las derivadas del proceso restaurador) y estimar su nivel de seguridad. Sin embargo, el adecuado conocimiento del material (la fábrica) y de su particular comportamiento condiciona el método y resultado del análisis a realizar. Los estudios realizados (1-4) indican que las técnicas disponibles requieren un mayor conocimiento de los materiales con que están construidos estos edificios.

La fábrica es un material heterogéneo constituido por bloques y juntas, generalmente rellenas de mortero. En las catedrales góticas los bloques suelen ser de piedra, de forma relativamente regular aunque con diferente origen y propiedades. El mortero suele ser de cal o de cemento y cal, incluso con elementos añadidos como pelo de animal, y con frecuencia está deteriorado o incluso ha desaparecido. El comportamiento mecánico de la fábrica, como material compuesto, es complejo y tiene como característica fundamental su baja resistencia a tracción. Este aspecto es muy importante y ha condicionado la forma de las catedrales góticas. A esto se suma que la fábrica conforma elementos estructurales muy variados: muros de carga compuestos por dos o más hojas de mampostería y rellenos con hormigón en masa y/o cascotes, pilas macizas o rellenas con cascotes, arcos, bóvedas cuyos senos tienen análogos rellenos, etc. Todo ello da una idea de la dificultad para obtener datos precisos de las propiedades mecánicas de la fábrica, como material compuesto, que con frecuencia incluso varían de una zona a otra dentro del mismo elemento estructural.

\section{INTRODUCTION}

Effective conservation of Gothic cathedrals is a major challenge involving a number of disciplines, from historical research (records of building construction and later modifications and interventions) to the application of modern techniques for conserving materials. In addition to undertaking urgent interventions, conservation programmes should anticipate possible problems, such as cumulative damage and fatigue due to traffic, pollution-induced decay or differential foundation settling prompted by nearby works or vibrations, among others. Experience has shown that a historical structure that is still standing centuries after it was built may undergo severe decay or even collapse if such issues are not addressed. For that reason structural analysis and assessment of structural safety are often included in a cathedral's Management Plan.

Structural analysis can identify a building's strength mechanisms, predict the stress to which it may be subject (including restoration-induced stress) and estimate safety levels. Analytical methods and findings are contingent upon a sufficient understanding of the material (masonry) and its specific behaviour, however. Prior studies (1-4) indicate that the techniques available call for a fuller understanding of the materials of which such buildings are made.

Masonry is a heterogeneous material comprising blocks and (typically mortar-filled) joints. In Gothic cathedrals the blocks are usually made of fairly uniform cut stone of different origins and properties. The mortar, generally lime or cement and lime with occasional additions such as animal fur, is often decayed or worn to disappearance. The mechanical behaviour of masonry as a composite material is complex and characterized in particular by its low tensile strength. This very important consideration has conditioned the form of Gothic cathedrals. Moreover, masonry is used in a wide variety of structural members: bearing walls consisting in two or more leaves of rubble masonry filled with bulk concrete and/or debris, solid or rubblefilled piers, arches, vaults having spandrels with analogous fills, and so on. All the foregoing is indicative of the difficulty involved in obtaining accurate data on the mechanical properties of this composite material, which may even vary from one part of the same structural member to another. 
Para el análisis estructural de edificios históricos se dispone de diferentes métodos y herramientas, que van desde métodos analíticos basados en la mecánica racional (resolubles manualmente), pasando por los métodos gráficos de la estática y llegando a complejos métodos computacionales que incorporan la no linealidad en sus diversos aspectos (geométrica y del material). Cada uno tiene su ámbito de aplicación y requiere datos sobre el material adecuados a su nivel de análisis. Un método más sofisticado no conduce necesariamente a un resultado más preciso. El buen hacer y la experiencia del analista estructural seleccionará y combinará los más adecuados al fin buscado y los datos disponibles. Una discusión más profunda sobre el particular se recoge en (5-7).

ICOMOS (8) ha propuesto unas Recomendaciones para el Análisis, Conservación y Restauración del Patrimonio Arquitectónico. La Figura 1 muestra la metodología propuesta, de carácter iterativo, en la que a partir de los primeros datos se obtiene la respuesta estructural, un diagnóstico previo y una evaluación estructural. De forma iterativa se refina el análisis con nuevos datos hasta alcanzar el nivel de análisis requerido, bien de comportamiento global de la estructura o de detalle, en el caso de elementos estructurales particulares.
The methods and tools in place for the structural analysis of historic buildings range from analytical methods based on rational mechanical engineering (that can be solved by hand) and graphic methods for determining static behaviour, to complex computations that accommodate the non-linearity of both geometry and materials. Each has its own scope of application and requires data on the material suited to the level of analysis involved. More sophisticate methods need not necessarily yield more accurate results. Structural analysts select and combine the approaches best suited to the objective pursued and the available data based on good practice and experience. A more detailed discussion of this issue can be found in (5-7).

ICOMOS (8) has proposed a series of recommendations for analyzing, conserving and restoring the architectural heritage. Figure 1 shows the iterative method proposed, in which a structural response, a preliminary diagnosis and a structural assessment are obtained from the initial data. The analysis is then iteratively refined by entering new data to attain the analytical level required, i.e., either the structure as a whole or details of specific structural members.

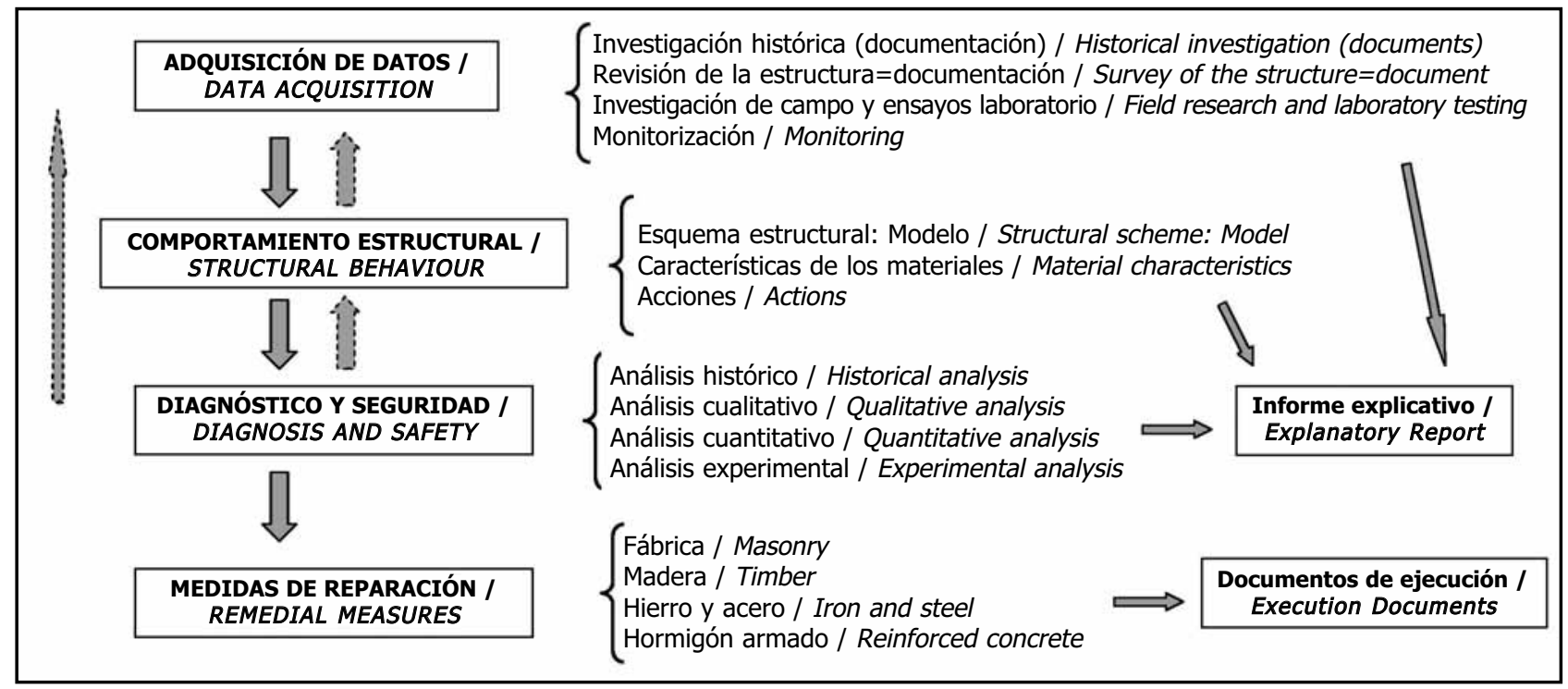

Figura 1. Diagrama de flujo con la metodología para intervenciones estructurales propuesta por ICOMOS (1) y (8). Figure 1. ICOMOS (1) and (8) methodology for structural interventions.

Este artículo tiene como objetivo mostrar cómo pueden afectar las propiedades de la fábrica al comportamiento estructural de la catedral de León. Para ello se estudia la sección transversal de la catedral y se evalúa cómo es su respuesta estructural en función de las propiedades del material cuando se ve sometida a
The present article aims to show how masonry properties can affect the structural behaviour of Leon cathedral. To this end, it discusses the study of a crosssection of the cathedral and the assessment of the structural response of its constituent materials when exposed to the actions to which it would normally have 
las acciones que razonablemente puede sufrir a lo largo de su historia: sobrecargas accidentales por viento, nieve y cambios de temperatura, y asientos diferenciales. El trabajo muestra de forma práctica cómo aplicar la metodología propuesta por ICOMOS (8), y adaptada por los autores a la catedral de León (3), cuando se pretende evaluar el nivel de seguridad, y su posible evolución, en el Plan Director de la catedral. El trabajo permite identificar qué variables, cuya alteración afecta de forma más directa al comportamiento de la estructura y su seguridad. El trabajo presenta los resultados del análisis de sensibilidad que permiten identificar las variables más influyentes. El nivel de análisis es el de comportamiento global de la sección transversal. Se emplean los datos sobre el material y la geometría disponibles $(9,10)$ y el resultado obtenido se encuadra en el nivel que permitiría decidir qué zonas deberían analizarse con más detalle y qué variables deberían medirse in situ en caso de que la estructura mostrase signos de daño.

El artículo se ha organizado del siguiente modo: primero se hace una breve presentación sobre los aspectos particulares de la fábrica de la catedral de León. A continuación se presentan las variables objeto de estudio y los valores que se adoptan para ellas. Se presenta el análisis de sensibilidad del comportamiento estructural y se discuten los resultados obtenidos. Finalmente se presentan las conclusiones y comentarios finales.

\section{LA FÁBRICA DE LA CATEDRAL DE LEÓN}

La fábrica de la catedral de León está constituida fundamentalmente por sillares relativamente regulares de origen calizo. Desde hace muchos años ha sufrido problemas por el deterioro de la piedra. De los Ríos (9) ya apuntaba en 1895, como posible causa de la ruina de la catedral de León, la deficiente ejecución de la fábrica junto a la mala calidad de la piedra:

La fábrica fue emprendida con una piedra asaz dura [...] Su cantera hubo de agotarse ó de ser abandonada por el administrador y maestro de la obra para inclinarse á otra más blanda, laborable y económica, y con ella, por desgracia de monumento, continuáronse los tres pilares torales, la torre de las campanas ó del Norte, y, en suma, toda la parte superior $y$ mayor de la fábrica. Calcárea, de fractura y aspecto terroso, [...] señálase por sus pésimas condiciones y fatales resultados, invadiendo más porción del edificio de la que hubiera sido conveniente.

En varias zonas se combinaron piedras de muy poca altura en relación al espesor de las juntas -en algunos been subjected throughout its history: accidental service loads due to wind, snow, variations in temperature and differential settlement. The paper contains a practical example of how to apply the ICOMOS (8) proposal, adapted by the authors to Leon Cathedral (3), to assess safety levels and their possible evolution as part of the cathedral's Management Programme. The study identifies the variables whose alteration affects structural behaviour and safety most directly and discusses the analytical findings on which that identification is based. The analysis is conducted for overall behaviour of the cross-section, using the available data on material and geometry $(9,10)$. The results obtained provide sufficient information to determine which areas should be analyzed in greater detail and which variables should be measured in situ if the structure shows signs of damage.

The article begins with a brief introduction of the specificities of Leon cathedral masonry. This is followed by a description of the variables studied and the values adopted for each. The sensitivity analysis findings on structural behaviour are then presented and discussed and the respective conclusions are drawn. The paper ends with a series of final remarks.

\section{LEON CATHEDRAL MASONRY}

Leon cathedral masonry consists essentially of fairly regularly hewn limestone ashlars. Stone decay has been a problem for many years. As early as 1895, de los Ríos (9) suggested that flawed masonry and poor stone quality could lead to ruin in Leon Cathedral:

\begin{abstract}
Masonry was undertaken with a fairly hard stone [...] The quarry must have been depleted or abandoned by the administrator and master builder and the rock replaced with softer, more workable and inexpensive stone which was used, to the detriment of the monument, in the three arch rib columns, the bell or north tower and the entire upper and greater part of the masonry. Calcareous, with an earthy appearance [...] distinguishable for its poor condition and dreadful results, invading a larger portion of the building than would have been desirable.
\end{abstract}

Stones of scant height in comparison to the thickness of the joints (which in some walls are five or six cm thick) 
muros el espesor de junta alcanza los 5 ó $6 \mathrm{~cm}-$ dando lugar a una fábrica excesivamente deformable y fácilmente aplastable. Este aspecto es confirmado en (4) para otras estructuras pétreas medievales.

Trabajos más recientes, véase Marcos (10), identifican los tipos de roca presentes en la fábrica de la catedral de León: dolomías cristalinas (piedra de Boñar), calizas margosas (piedra del País) y calizas bioclásticas (piedra de Hontoria). De los Ríos (9) achacó al tipo de piedra alguno de los males de la catedral de León:

[...] y la tan apreciada piedra de Boñar, heladiza también, saltó en las restauraciones y se redujo a polvo, aun en su clase más selecta.

empleando [...] la piedra calcárea de Ontoria junto á Burgos, con la cual erigióse la hermosa catedral de esta ciudad, más venturosa en esto que la de León.

La piedra de Boñar se ha empleado en gran parte de la iglesia (torre, hastial y arbotantes del Sur, torre de la Limona, etc.), el claustro y el exterior de las capillas. Es una piedra que generalmente presenta un buen nivel de conservación (3).

La piedra del País presenta un gran deterioro en las zonas expuestas a la intemperie. Aparece, entre otras zonas, en la torre y arbotantes del Norte, pórtico y hastial Oeste y en el interior del templo (3).

Por último, la piedra de Hontoria, menos presente en la catedral y de más reciente utilización en obras de restauración, aparece en balaustradas, ventanales, barandillas y otros adornos menores. Su estado de conservación no es bueno, especialmente si se tiene en cuenta su reciente colocación.

La Figura 2 muestra una foto del ábside de la catedral de León. En ella se distinguen los tres tipos de piedra mencionados y muestran su diferente grado de deterioro. La de Boñar es más clara (entre rosácea y amarillenta), la del País es más oscura (rojiza con manchas oscuras) y la de Hontoria es también clara (blanca con tonos grisáceos) y en los paramentos que no son verticales suele estar cubierta por líquenes. Como se puede observar en esta Figura, hay una cierta aleatoriedad en la colocación de los distintos tipos de piedra que responde a varias causas $(3,10)$ : trabajo de varios canteros en la construcción, empleo de sillares procedentes de construcciones previas y sustituciones en reparaciones sufridas a lo largo de la historia de la catedral. were combined in some areas, resulting in overly deformable and readily crushable masonry. This practice was reported in (4) in connection with other Medieval stone structures.

More recent studies, see Marcos (10) identified the type of rock present in Leon Cathedral masonry: crystalline dolostone (Boñar stone), marlstone (País stone) and bioclastic limestone (Hontoria stone). De los Ríos (9) attributed some of Leon Cathedral's ills to the type of stone:

[...] and even the most select type of the highly esteemed, frost-sensitive Boñar stone, crumbled to dust during restoration.

using [...] calcareous stone from Ontoria near Burgos to build the city's handsome cathedral, which was more fortunate in this respect than Leon Cathedral.

Boñar stone was used in much of the church (south tower, gable and buttresses, Limona Tower and so on), the cloister and the chapel exteriors. This stone is in generally good condition (3).

Where exposed to weathering, País stone is severely decayed. This stone was used, among others, in the north tower and buttresses, west portal and gable and inside the temple (3).

Lastly, Hontoria stone, used less and more recently in the cathedral (for restoration work), is found in balustrades, windows, banisters and other lesser adornments. It is in scantly satisfactory condition, particularly considering the relatively short time lapsing since it was laid.

Figure 2 contains a photo of the Leon cathedral apse, showing the three types of stone and their differing degrees of decay. Boñar stone is lighter in colour (from pinkish to yellowish), País is darker (reddish with dark stains) and Hontoria is likewise light (white with greyish tones) and on non-vertical surfaces generally covered with lichens. The figure illustrates the apparently random placement of the various types of stone, for which there are several explanations $(3,10)$ : participation of several quarrymen in the works, use of demolition ashlars and repairs performed on the cathedral throughout its history. 


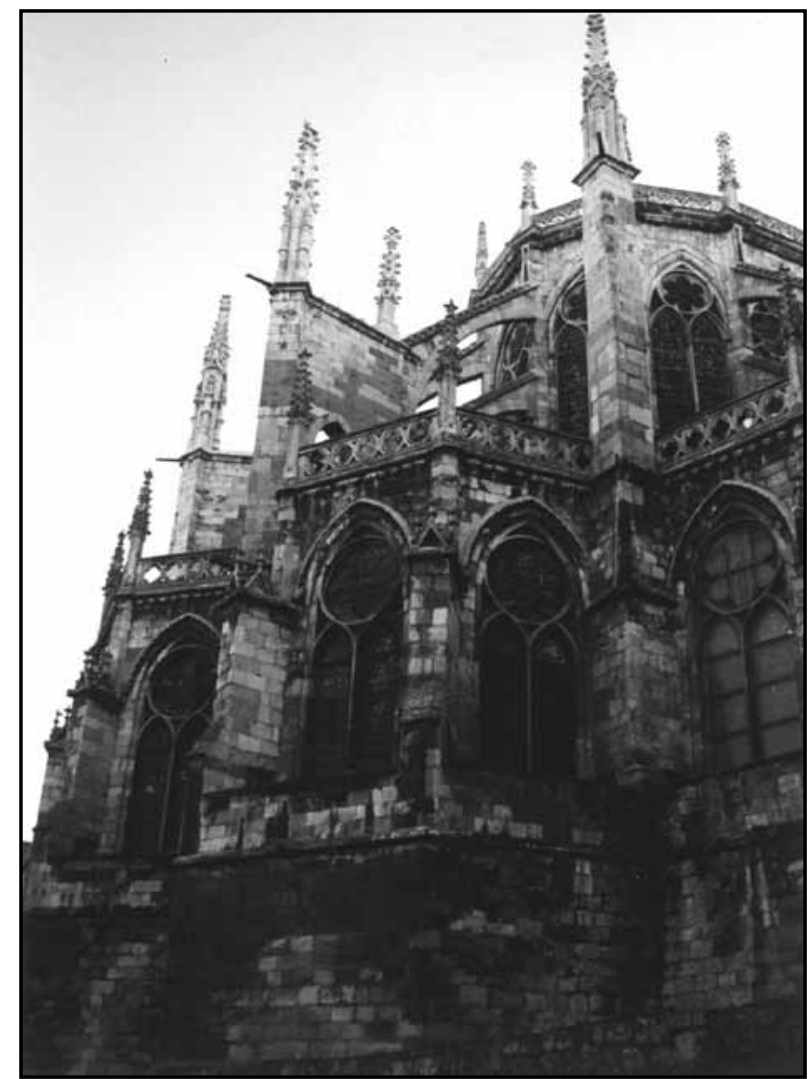

Figura 2. Ábside de la catedral de León en el que se pueden identificar los tipos de piedra que forman la fábrica.

Figure 2. Leon cathedral apse showing different types of stone.

\section{CONSIDERACIONES SOBRE LAS VARIABLES MECÁNICAS DE LA FÁBRICA DE LA CATEDRAL DE LEÓN}

Se dispone de varias normas y recomendaciones para caracterizar y/o ejecutar la fábrica: ASTM C144 (11), ASTM C67 (12), ASTM C1196 (13), ASTM C1197 (14), ASTM E518 (15), EN-1996-1.1 (16), ACI 530 (17), RILEM TC-127-MS (18) y las españolas FL-90 (19), p.i.e.t. 70 (20) y UNE-EN-772 (21). Ninguna hace referencia explícita a la fábrica antigua. Además hay un gran vacío bibliográfico sobre ensayos mecánicos en fábrica antigua, tanto in situ como en laboratorio (22).

Los tratados de los siglos XIX y principios del XX consideran la tensión de trabajo de la fábrica como la décima parte de la tensión de rotura de las piedras. Huerta (22) propone valores de tensiones de trabajo para algunas estructuras de fábrica de edificios de más de 100 años de antigüedad (Tabla 1). La mayor parte de los trabajos realizados hacen referencia a fábrica de ladrillo actual (23).

\section{MECHANICAL VARIABLES IN LEON CATHEDRAL MASONRY}

A number of standards and recommendations for masonry characterization and/or construction are in place: ASTM C144 (11), ASTM C67 (12), ASTM C1196 (13), ASTM C1197 (14), ASTM E518 (15), EN-1996-1.1 (16), ACI 530 (17), RILEM TC-127-MS (18) and Spanish standards FL-90 (19), p.i.e.t. 70 (20) and UNE-EN-772 (21). None makes specific reference to historic masonry. Moreover, there is a dearth of literature on both laboratory and in situ mechanical testing of such masonry (22).

Nineteenth and early twentieth century treatises regarded masonry working stress to be one tenth of its crushing strength. Huerta (22) proposed working stress values for a number of masonry structures in buildings over 100 years old (Table 1). Most of the literature refers to today's brick masonry (23). 
Tabla 1 / Table 1

Tensiones de trabajo estimadas de la fábrica de edificios históricos (22).

Estimated working stress on masonry in historic buildings (22).

\begin{tabular}{|c|c|}
\hline Edificios históricos / Historical buildings & $\begin{array}{c}\text { Tensión de trabajo / } \\
\text { Estimated stress (MPa) }\end{array}$ \\
\hline Pilares de la cúpula de San Pedro de Roma / Piers of S. Peter's Dome (Rome) & 1.7 \\
\hline Pilares de la cúpula de San Pablo de Londres / Piers of S. Paul's Dome (London) & 1.9 \\
\hline Pilares de la cúpula de los Inválidos de París / Piers of Invalidos Dome (Paris) & 1.4 \\
\hline Pilares de la cúpula de Santa Genoveva de París / Piers of S. Genevieve's Dome (Paris) & 2.9 \\
\hline Columnas de la iglesia de San Pablo Extramuros de Roma / Piers of outside the town S. Paul's church (Rome) & 2.0 \\
\hline Columnas de la iglesia de Toussaint d Angers / Piers of Toussaint d 'Angers's church & 4.4 \\
\hline Pilares de la cúpula de Santa Sofía de Constantinopla / Piers of S. Sophia Dome (Constantinople) & 2.2 \\
\hline Pilares de la catedral de Palma de Mallorca / Piers of Palma de Mallorca's cathedral & 2.2 \\
\hline
\end{tabular}

Los valores propuestos en la Tabla 1 confirman el bajo nivel de tensiones habitual en este tipo de construcciones, muy lejos, en general, de la resistencia a compresión de la fábrica. En el caso de la catedral de León no se dispone de valores experimentales de las propiedades mecánicas de los distintos tipos de la fábrica, por lo que para este trabajo se han estimado a partir de datos de la bibliografía.

La resistencia a compresión se ha estimado a partir de la propuesta de Ohler (24) para la resistencia a compresión de la fábrica antigua [1]:
The values proposed in Table 1 confirm that the stress level in such structures is generally far lower than masonry compressive strength. Since no experimental values are available for the mechanical properties of the various types of masonry in Leon Cathedral, they were estimated from data given in the literature for the present study.

Compressive strength was estimated from Ohler's (24) proposal for historic masonry [1]:

$$
f=\frac{a f_{b}}{1+10 b \alpha}
$$

donde $f$ es la resistencia a compresión de la fábrica, $f_{b}$ la resistencia a compresión de la pieza, $\alpha$ la relación entre el espesor de los tendeles y el espesor de la pieza, $\boldsymbol{a}$ y $\boldsymbol{b}$ parámetros de la envolvente de rotura (véase Tabla 2). La Tabla 3 muestra la resistencia a compresión de la fábrica de León obtenida con la ecuación [1] para los tipos de piedra presentes en la estructura de la catedral de León. La dispersión observada es consecuencia de los diferentes valores de las resistencias máximas de compresión para cada tipo de piedra. where $\boldsymbol{f}$ is masonry compressive strength, $f_{b}$ block compressive strength, $\alpha$ the ratio between bed joint thickness and block thickness, and $\boldsymbol{a}$ and $\boldsymbol{b}$, failure envelope parameters (see Table 2). Table 3 gives the masonry compressive strength obtained with equation [1] for the three types of stone present in Leon Cathedral. The dispersion observed is the result of the different maximum compressive strength values found for each stone.

Tabla 2 / Table 2

Valores de los parámetros a y b de $\alpha$ (24).

Values of parameters $a$ and $b$ for $\alpha$ (24).

\begin{tabular}{|c|c|c|}
\hline$\alpha$ & $\mathbf{a}$ & $\mathbf{b}$ \\
\hline $\mathrm{a} \leq 0.02$ & 1.000 & 2.218 \\
\hline $0.02<\mathrm{a}<0.15$ & 0.811 & 0.960 \\
\hline$\alpha \geq 0.15$ & 0.662 & 0.662 \\
\hline
\end{tabular}

La Tabla 3 también muestra los valores de la resistencia a compresión de la fábrica de la catedral de León aplicando distintas normas y recomendaciones. Los valores obtenidos con la ecuación [1] son del mismo orden que los propuestos por estas normas y recomendaciones.
Table 3 shows the compressive strength values for Leon Cathedral masonry found by applying different standards and recommendations. The values obtained with equation [1] are of the same order of magnitude as the ones found as proposed in such texts. 
Tabla 3 / Table 3

Resistencia a compresión, a tracción y módulo de deformación de la fábrica de la catedral de León estimada a partir de normas y recomendaciones.

Compressive strength, tensile strength and modulus of deformation of the masonry in Leon cathedral estimated as specified in standards and recommendations.

\begin{tabular}{|c|c|c|c|c|c|c|c|c|}
\hline & $\begin{array}{c}\text { Tipo de piedra } \\
\text { / Stone }\end{array}$ & $\begin{array}{c}\text { Ohler } \\
\text { (24) }\end{array}$ & $\begin{array}{c}\text { Piet } 70 \\
(20)\end{array}$ & ACI (17) & CIB (25) & EC-6 (16) & $\begin{array}{c}\text { DIN } 18554 \\
\text { (26) }\end{array}$ & UIC (27) \\
\hline \multirow{3}{*}{$\begin{array}{c}\text { Resistencia a compresión } \\
\text { de la fábrica / Compression strength } \\
\mathrm{f}(\mathrm{MPa})\end{array}$} & Boñar & $30-38$ & \multirow{3}{*}{3} & \multirow{3}{*}{$3.1-2.76$} & \multirow{3}{*}{ 4.7-5.9 } & $12-14$ & $11-12.7$ & \multirow{3}{*}{-} \\
\hline & Hontoria & 13 & & & & $3-9.6$ & $4-9.6$ & \\
\hline & País & $3.8-22$ & & & & 6.7 & 7.4 & \\
\hline \multirow{3}{*}{$\begin{array}{c}\text { Resistencia a tracción de la fábrica / } \\
\text { Tensile strength } \\
\mathrm{f}_{\mathrm{t}}(\mathrm{MPa})\end{array}$} & Boñar & - & \multirow{3}{*}{0.3} & \multirow{3}{*}{$\begin{array}{l}0.16-0.103 \\
0.33-0.207\end{array}$} & \multirow{3}{*}{ - } & \multirow{3}{*}{-} & \multirow{3}{*}{ - } & \multirow{3}{*}{ - } \\
\hline & Hontoria & - & & & & & & \\
\hline & País & - & & & & & & \\
\hline \multirow{3}{*}{$\begin{array}{c}\text { Módulo de deformación longitudinal / } \\
\text { Modulus of deformation } \\
\mathrm{E}(\mathrm{GPa})\end{array}$} & Boñar & - & \multirow{3}{*}{4.5} & \multirow{3}{*}{-} & \multirow{3}{*}{-} & $12-14$ & \multirow{3}{*}{-} & $10.5-12.6$ \\
\hline & Hontoria & - & & & & $3-9.6$ & & $4.2-15.4$ \\
\hline & País & - & & & & $6.7-7.4$ & & $3.5-21$ \\
\hline
\end{tabular}

Como se ha indicado, la resistencia a tracción de la fábri$c a, f_{t}$, suele ser muy baja. Esto se debe generalmente a la débil cohesión que presentan las juntas en las uniones pieza-mortero. El valor de la resistencia a tracción de la fábrica no suele superar la décima parte de su resistencia a compresión. Si bien, la fábrica normalmente no trabaja a tracción. La Tabla 3 muestra los valores de la resistencia a tracción según la propuesta de las normas ACI 530 (17) y p.i.e.t. 70 (20).

El módulo de deformación longitudinal de la fábrica, $\boldsymbol{E}_{\boldsymbol{r}}$ ha sido poco estudiado, y especialmente el referido a la fábrica de sillería. Se han realizado pocos ensayos y los datos que aparecen en la bibliografía son muy diferentes, variando entre 2,5 y $40 \mathrm{GPa}$ (28). Autores como Pieper (29) proponen valores en función del tipo de aparejo: 2 GPa para mampostería y 20 GPa para sillería.

A falta de datos experimentales, para la catedral de León se adoptan los valores del módulo de elasticidad propuestos por las distintas normativas y recomendaciones y que se recogen en la Tabla 3.

Algunos autores proponen fórmulas empíricas para calcular el valor del módulo de deformación longitudinal de la fábrica; en la referencia (3) se recogen con detalle. Todas estas expresiones, correspondientes a ajustes empíricos, deben emplearse con prudencia, pues su ámbito de aplicación se reduce a un tipo de fábrica con unos componentes particulares.

\section{DESCRIPCIÓN DE LAS VARIABLES ADOPTADAS EN EL ESTUDIO DE SENSIBILIDAD}

En el apartado anterior se ha puesto de manifiesto que no hay una normativa que proporcione datos precisos sobre las propiedades mecánicas de la fábrica antigua. Además, en el
As noted earlier, masonry tensile strength, $f_{t}$, is usually very low. This is generally due to weak block-mortar bonding. As a rule, masonry tensile strength is no more than one tenth of its compressive strength. Masonry is not, however, usually subjected to tensile stress. Table 3 gives the tensile strength values proposed by standards ACI 530 (17) and p.i.e.t. 70 (20).

The longitudinal modulus of deformation, $E$, has been scantly studied in masonry, and even less for ashlar masonry. Very few tests have been conducted and the values reported in the literature vary widely, from 2.5 to 40 GPa (28). Authors such as Pieper (29) have proposed values that depend on the bond arrangement: $2 \mathrm{GPa}$ for rubble masonry and $20 \mathrm{GPa}$ for ashlar stone.

In the absence of experimental data, the yield stress values proposed by the various standards and recommendations and shown in Table 3 were adopted for Leon cathedral.

A number of authors have proposed empirical formulas to calculate the longitudinal modulus of deformation in masonry, listed in detail in (3). All such expressions deriving from empirical fits must be used cautiously, however, for their scope of application is limited to a single type of masonry with specific components.

\section{SENSITIVITY STUDY VARIABLES}

The preceding section shows that no rules are in place to obtain accurate data on the mechanical properties of historic masonry. Moreover, in the specific case of Leon 
caso particular de la catedral de León, tampoco se dispone de datos experimentales suficientes para realizar el cálculo estructural de la sección transversal con suficiente fiabilidad. Dicho cálculo es necesario para evaluar la seguridad de la estructura y su comportamiento frente a posibles intervenciones y reparaciones. Tan sólo se dispone de una clasificación del tipo de piedra empleado (10) y de la estimación de sus posibles valores mostrada en la Tabla 3.

La obtención de los datos es difícil y, en algunos casos, se puede considerar casi imposible: no existen memorias ni planos de muchas de las actuaciones realizadas a lo largo de los casi ocho siglos de historia de la catedral, no se conceden permisos para realizar sondeos y catas en la catedral sin una justificación importante (la catedral está en servicio y su conservación es buena), aparte de que su coste es muy elevado. Tampoco se dispone de un levantamiento de planos fiel a la realidad.

De acuerdo a la metodología propuesta por ICOMOS (8), adaptada por los autores a esta catedral (3), se opta por realizar un análisis de sensibilidad del comportamiento estructural frente a las variables que dependen del material que constituye la fábrica, especialmente las propiedades mecánicas. En este trabajo se presenta el estudio de la sección transversal como la parte de la estructura más representativa de la catedral. Se remite al lector interesado en los resultados del estudio correspondiente a la bóveda del crucero y otros elementos estructurales de importancia, como arbotantes y botareles, a la referencia (3). El análisis de sensibilidad permitirá identificar los factores que más afectan al comportamiento de la estructura y ayudará a optimizar los recursos disponibles para la experimentación y la auscultación.

Como variables de cálculo se adoptan el módulo de deformación de la fábrica, las condiciones de apoyo de pilares y botareles, las deformaciones transversales de la directriz de los pilares y la variabilidad de las cargas actuantes sobre la estructura (peso propio, viento, nieve y temperatura).

De las variables mecánicas de la fábrica se ha seleccionado solo el módulo de deformación por ser la que más puede afectar al comportamiento de la estructura. Dado el bajo nivel de tensiones que solicita la fábrica (véase Tabla 1) no parece que la resistencia a compresión sea, de entrada, un parámetro determinante. Sin embargo, una mayor o menor deformabilidad puede condicionar la respuesta estructural, puesto que se trata de estructuras que resisten por su forma $(1,22)$. Respecto a la resistencia a tracción, condicionada por la posible apertura de juntas entre bloques, su incorporación requiere el empleo de métodos de cálculo que contemplen fisuración y/o apertura de juntas, lo que no se contempla en esta primera fase. No obstante, la referencia (3) muestra el cálculo del arbotante, en el que sí se contempla la posible apertura de juntas entre bloques. cathedral, the lack of sufficient experimental data is an obstacle to performing any reliable structural engineering on the cross-section. And yet such engineering is needed to assess structural safety and behaviour in the event of possible interventions and repairs. The only information available is a classification of the type of stone used (10) and an estimate of its possible values as given in Table 3.

Data collection is difficult, not to say impossible in some cases: no descriptions or drawings are at hand for many of the interventions undertaken in the nearly eight centuries since the cathedral was built, permission is not granted for probes or cutouts in the cathedral unless for some pressing reason (the cathedral is in use and in good condition), and the associated costs are high. Nor are there any accurate drawings of the structure as it stands today.

Pursuant to the methodology proposed by ICOMOS (8), adapted by the authors to this cathedral (3), a sensitivity analysis of the structural behaviour was conducted to test the variables that depend on the masonry material, and particularly the mechanical properties of that material. This article discusses the study of a crosssection as the structure most representative of the cathedral. Readers interested in the findings of studies conducted on the transept vault and other major structural members such as the buttresses and piers are referred to reference (3). By identifying the factors impacting structural behaviour most heavily, sensitivity analysis helps optimize the resources available for experimentation and examination.

The variables used included the masonry modulus of deformation, support conditions in columns and piers, horizontal column deformation and the loads acting on the structure (self weight, wind, snow and temperature).

The modulus of deformation was the only mechanical variable chosen, for it is the one liable to affect structural behaviour most intensely. In light of the low stress on the masonry (see Table 1), compressive strength would not initially appear to be a determining parameter. Greater or less deformability, however, may condition structural response, since in these structures strength is form-dependent $(1,22)$. The inclusion of tensile strength, in turn, which is conditioned by the possible opening of inter-block joints, calls for engineering methods able to accommodate joint cracking and/or opening, neither of which is considered in this first phase. Nonetheless, reference (3) describes the engineering for a buttress in which the possible opening of inter-block joints is broached. 
En cuanto a las condiciones de contorno de la estructura, se ha contemplado el posible asiento relativo de un pilar y del botarel. La razón es que la catedral esté cimentada sobre otra construcción previa, con planta de menor tamaño, de forma que parte de la catedral está sobre la antigua iglesia y otra parte sobre terreno natural y de relleno.

La deformación transversal de los pilares a la altura de la zona de apoyo de las naves bajas es muy frecuente en estos edificios como consecuencia del proceso de construcción. Conviene estudiar su influencia dado que las deformaciones diferidas y el propio deterioro de la fábrica puede incrementarlas.

Por último, las acciones del viento, la nieve y la temperatura parece imprescindible contemplarlas. La variabilidad del peso propio puede chocar de entrada en la selección de variables realizada. Responde a varias razones. La primera es que los bloques de piedra tienen naturaleza y pesos específicos distintos (10) y su distribución es más o menos aleatoria (véase Figura 2). La segunda es que los botareles, pilares y bóvedas contienen rellenos cuyo peso puede variar en función de la humedad, incluso se ha dado el caso de actuaciones que han eliminado el relleno de alguno de estos elementos, comprometiendo seriamente la estabilidad de la estructura. La tercera es que elementos como los botareles, con sus pináculos incrementadores de peso, dan estabilidad a la estructura gracias a su peso, y una reducción de sección (por deterioro de la piedra) o incluso su derrumbe (por acciones extraordinarias) puede comprometer la estabilidad de la estructura; una forma sencilla, en una primera evaluación, de contemplar estos aspectos es modificar el peso propio sin variar la geometría de la malla de elementos finitos.

A continuación se muestran los valores adoptados para estas variables en el estudio de sensibilidad. Cada variable se identifica con una letra mayúscula y se le asigna el número correspondiente al caso de estudio.

- Módulo de deformación longitudinal de la fábrica (E)

- [E1]: Valor de 15 GPa para todas las dovelas de la sección.

- [E2]: Valor del módulo de deformación distribuido aleatoriamente en las dovelas de la sección. Los valores adoptados son 1,5; 15 y $150 \mathrm{GPa}$.

- [E3]: Adopción de tres valores diferentes para los tres tipos de piedra de la sección, según los valores propuestos por Marcos (10) y la distribución observada en la sección transversal real: $15 \mathrm{GPa}$ (piedra de Boñar), $12 \mathrm{GPa}$ (piedra de Hontoria) y 1 GPa (piedra de País).
Since the cathedral was built over an older church with a smaller footprint, the boundary conditions considered for the structure included possible differential column and pier settling. In other words, while part of the cathedral stands on the older church, the rest of the foundation lays on natural soil and backfill.

Horizontal deformation in columns at the abutment with the lower naves is common in these buildings as a result of the construction process. The effect of such deformation should be studied, for it may be accentuated by deferred strain and masonry decay.

Lastly, the study of wind, snow and temperature actions appears to be imperative. Perhaps surprisingly at first, self weight was chosen as a variable for a number of reasons. Firstly, the stone blocks differ in nature and specific weight (10) and are distributed more or less randomly (see Figure 2). Secondly, piers, columns and vaults contain fills whose weight may vary depending on the humidity and which in some cases have even disappeared during repair and restoration, seriously compromising structural stability. Thirdly, members such as piers, with their weighty pinnacles, stabilize the structure and any reduction in their section (due to stone decay) or possible collapse (as a result of extraordinary actions) may compromise the structure's stability. One simple way of addressing such issues in a preliminary assessment is by modifying the self weight without varying the geometry of the finite element mesh.

The values adopted for these variables in the sensitivity study are given below. The upper case letter used to identify each variable is followed by a number designating a specific case or value.

- Masonry longitudinal modulus of deformation (E)

- [E1]: 15 GPa for all the voussoirs in the section.

- [E2]: modulus of deformation value randomly distributed in the voussoirs in the section. The values adopted were 1.5, 15 and $150 \mathrm{GPa}$.

- [E3]: the values proposed by Marcos (10) were assigned to each of the three types of stone in the section and distributed as observed in the actual cross-section. The numbers used were: $15 \mathrm{GPa}$ (Boñar stone), $12 \mathrm{GPa}$ (Hontoria stone) and $1 \mathrm{GPa}$ (País stone). 
- Vinculaciones o condiciones de apoyo de pilares y botareles (V)

- [V1]: Empotramiento en la base de los pilares y los botareles al mismo nivel.

- [V2]: Descenso impuesto de $5 \mathrm{~cm}$ en el botarel izquierdo.

- [V3]: Descenso impuesto de $5 \mathrm{~cm}$ en el pilar izquierdo.

- Deformaciones impuestas en la sección transversal (D)

- [D1]: Pilares de directriz recta.

- [D2]: Desplazamiento del pilar de $5 \mathrm{~cm}$ hacia el interior en la sección a la altura del apoyo de la bóveda de la nave baja y de $5 \mathrm{~cm}$ hacia el exterior a la altura del apoyo de la bóveda de la nave principal.

- [D3]: Idem para $10 \mathrm{~cm}$.

- Acciones de cálculo (A)

- [A1]: Peso específico constante para toda la sección de $25 \mathrm{kN} / \mathrm{m}^{3}$.

- [A2]: Peso específico variable aleatoriamente en las dovelas de la sección. Los valores del peso específico adoptados son: $25 \mathrm{kN} / \mathrm{m}^{3} ; 2,5 \mathrm{kN} / \mathrm{m}^{3} \mathrm{y}$ $250 \mathrm{kN} / \mathrm{m}^{3}$.

- [A3]: Viento, de acuerdo al Código Técnico de la Edificación (Anejo D del DS-SE-AE) (30) 0,73 $\mathrm{kN} / \mathrm{m}^{2}$ a barlovento (presión) y $0,55 \mathrm{kN} / \mathrm{m}^{2}$ a sotavento (succión).

- [A4]: Diferencia térmica entre el interior y exterior de la catedral de $20^{\circ} \mathrm{C}$.

Los valores adoptados para el módulo de deformación longitudinal, $\boldsymbol{E}_{\boldsymbol{l}}$ responden a las estimaciones realizadas por Marcos (10) para los tres tipos de piedra presentes en la catedral de León. Los valores del caso E2 son muy diferentes entre sí, con ello se pretende estudiar, mediante un caso límite, la influencia de la diferencia relativa elevada de módulos de elasticidad entre sillares en el comportamiento de la sección transversal. Este aspecto responde a que uno de los tipos de piedra sufra un deterioro grave. Se adopta una distribución aleatoria asignando estos valores a los elementos de la malla, pues la distribución real de sillares observados en algunas zonas de la catedral así parece.

El posible descenso del apoyo de pilares y botareles, $\boldsymbol{V}$, responde, como ya se ha indicado, a que la actual catedral está construida sobre la cimentación de una iglesia de menores dimensiones, con lo que parte de la cimentación de la actual catedral está sobre cimentación antigua y la otra sobre terrenos de relleno al lado de la antigua muralla. La experiencia muestra que las
- Support conditions in columns and piers (V)

- [V1]: fixed joints at the base of columns and piers.

- [V2]: descent imposed on left pier, $5 \mathrm{~cm}$.

- [V3]: descent imposed on left column, $5 \mathrm{~cm}$.

- Deformations imposed on cross-section (D)

- [D1]: straight columns.

- [D2]: column displacement $5 \mathrm{~cm}$ inward at the abutment with the lower nave and $5 \mathrm{~cm}$ outward at the abutment with the main nave.

- [D3]: idem, $10 \mathrm{~cm}$.

- Design actions $(A)$

- [A1]: constant specific weight for the entire section, $25 \mathrm{kN} / \mathrm{m}^{3}$.

- [A2]: randomly variable specific weight in section voussoirs. The specific weight values adopted were: $25 \mathrm{kN} / \mathrm{m}^{3}, 2.5 \mathrm{kN} / \mathrm{m}^{3}$ and $250 \mathrm{kN} / \mathrm{m}^{3}$.

- [A3]: wind, pursuant to the Spanish Technical Building Code (Annex D to SD-SE-AE) (30). The windward (pressure) value was $0.73 \mathrm{kN} / \mathrm{m}^{2}$ and the leeward (suction) value was $0.55 \mathrm{kN} / \mathrm{m}^{2}$.

- [A4]: difference between indoor and outdoor temperatures, $20^{\circ} \mathrm{C}$

The values adopted for the longitudinal modulus of deformation, $E$, were taken from Marcos's (10) estimates for the three types of stone present in Leon Cathedral. The widely varying values used in case E2 were intended to reflect a limit case to study the effect of the fairly large difference in ashlar stone yield stress values on crosssection behaviour. This case was studied to take account of the severe decay observed in one of the types of stone. The values were randomly attributed to mesh elements to simulate the actual distribution of ashlars observed in some parts of the cathedral.

The possible settlement of column and pier supports, $\boldsymbol{V}$, was included because, as noted earlier, the cathedral was built over a smaller church, so part of its foundations lie on the older structure and part on backfill land bordering the former city wall. Experience has shown that modern construction (particularly excavations for nearby basements and car parks) and vibrations may 
construcciones actuales (especialmente excavaciones próximas de sótanos y aparcamientos) y las vibraciones pueden generar asientos diferenciales entre pilares y botareles de un lado y otro de la catedral. El valor de $5 \mathrm{~cm}$ parece razonable para una construcción de estas características.

Las deformaciones impuestas, $D$, responden al estado real de la sección transversal en la que se aprecian a simple vista estos desplazamientos horizontales de la directriz de los pilares, hacia el interior de la sección a la altura del apoyo de la bóveda de la nave baja y hacia el exterior de la sección a la altura del apoyo de la bóveda de la nave principal. Estas deformaciones responden al proceso constructivo por empuje de las bóvedas antes de completar la sección transversal, acrecentadas por las deformaciones diferidas en el tiempo (3).

En cuanto a las acciones, $\boldsymbol{A}$, el caso A1 corresponde al peso específico aproximado de la fábrica. El A2 estudia, mediante caso límite, la influencia de la presencia o ausencia de los rellenos de cascotes en pilares y bóvedas, así como el posible colapso de parte de los elementos que por su peso dan estabilidad a la estructura, para ello se adoptan valores extremos entre 250 y $2,5 \mathrm{~N} / \mathrm{m}^{3}$. El caso A3 corresponde al viento; y el A4 a la diferencia máxima de temperatura entre el interior y exterior de la catedral, tanto en verano como en invierno. No se ha incorporado cálculo sísmico por ser una zona de muy baja sismicidad.

Se ha realizado un primer cálculo adoptando el valor en el caso "1" para cada variable (E1D1V1A1), como valor más probable. El cálculo se ha realizado con un programa de elementos finitos comercial, ABAQUS ${ }^{\circledR}$, en régimen elástico lineal. El cálculo ha permitido determinar las zonas de la sección transversal con mayor solicitación tensional o sometidas a mayores desplazamientos. Se ha empleado un programa comercial por simplicidad de cálculo, sin perjuicio de emplear programas más sofisticados, con modelos de cálculo específicos para fábrica, para el análisis de la sección transversal completa, o de alguno de sus elementos particulares.

El análisis de la respuesta estructural se ha basado en la tensión y los desplazamientos resultantes. La tensión por razones evidentes. El movimiento es determinante en estas estructuras que resisten por su forma. La Figura 3 muestra la malla de elementos finitos empleada y los puntos de mayor solicitación.

Los puntos indicados en la Figura 3 son los elegidos para el estudio de sensibilidad frente a las distintas combinaciones de variables antes enunciadas, correspondiendo cause differential settling between columns and piers on opposite sides of the cathedral. Five centimetres appears to be a reasonable value for such a structure.

Imposed deformation, $D$, reflects the actual state of the cross-section. Indeed, the horizontal deviation in columns, inward at the lower nave vault springing and outward at the main vault springing, is visible to the naked eye. Such deviations, the result of the presence of thrust from the vaults before cross-section construction was completed, have been intensified by deferred deformation (3).

$A 1$, the first of the action scenarios, $A$, reflects the approximate specific weight of the masonry. $A 2$ is the limit case study to determine the effect of the presence or absence of rubble fill in columns and vaults, or of the possible collapse of parts of members whose weight stabilizes the structure. To this end, extreme values ranging from 250 to $2.5 \mathrm{~N} / \mathrm{m}^{3}$ were adopted. Case A3 reflects the wind and $A 4$ the maximum temperature difference inside and outside the cathedral, both in summer and in winter. Seismic factors were not included because of the region's low seismicity.

The first trial calculation (E1D1V1A1) was run using option "1" as the most likely value for each variable. Calculations were performed with commercial finite element software, $A B A Q U S^{\circledR}$, in the linear elasticity mode. This calculation determined the areas of the crosssection subjected to greatest stress or displacement. Commercial software was used for its simplicity, without prejudice to using more sophisticated programs specifically developed for masonry to analyze either the entire cross-section or any one of its elements.

Analysis of the structural response was based on the resulting stress and displacement: stress for obvious reasons. Movement is a determinant in these structures, for their strength is form-dependent. Figure 3 shows the finite element mesh used and the points subject to the greatest stress.

The points outlined in Figure 3 were chosen to study structural sensitivity to the different combinations of variables described above, as follows: the top of the 


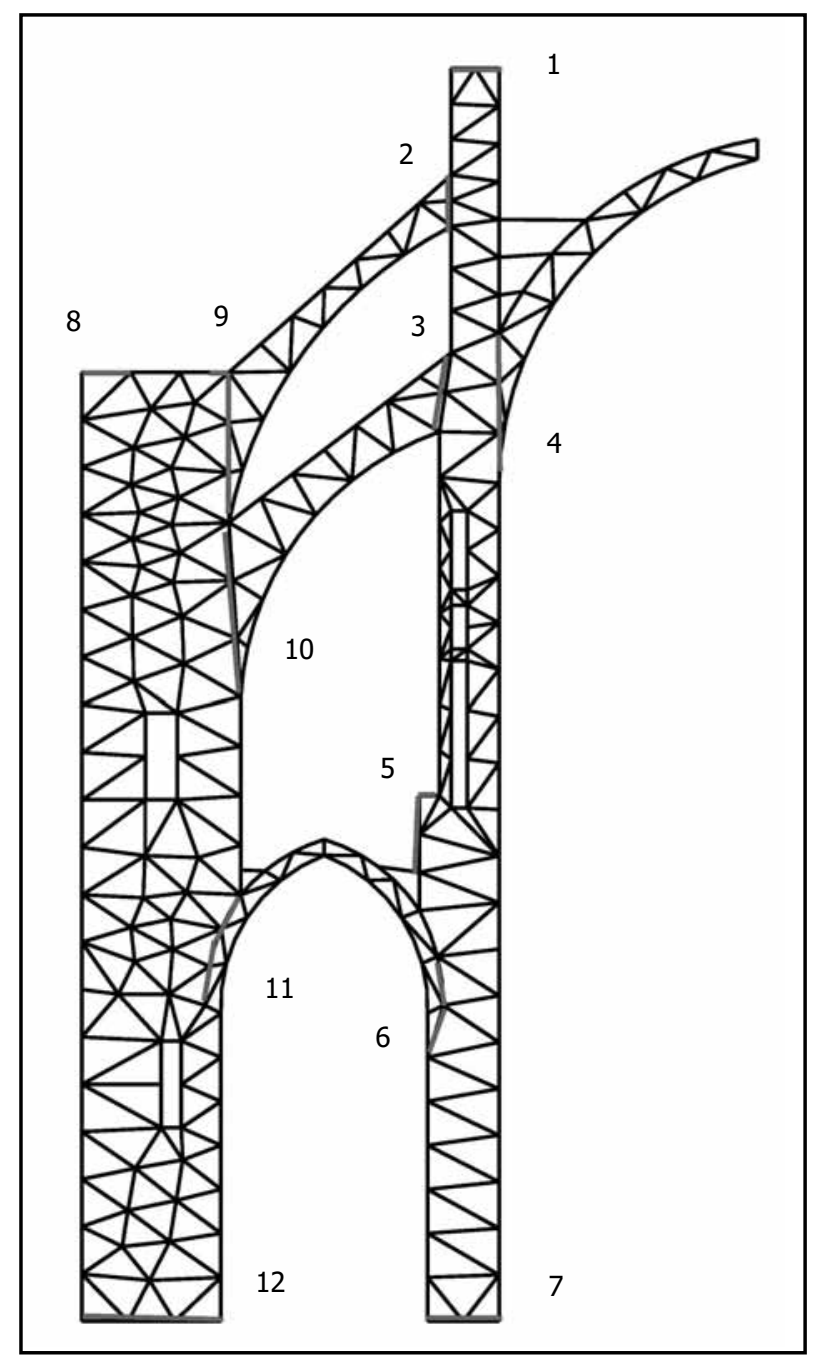

Figura 3. Malla de elementos finitos empleada en el cálculo en la que se indican las zonas críticas de la sección transversal adoptadas para el estudio de sensibilidad.

Figure 3. Finite element mesh of the cross-section showing points analyzed in the sensitivity study.

a la parte superior del pilar (punto 1), el apoyo del arbotante superior (punto 2), el apoyo del arbotante inferior (punto 3), el arranque de la bóveda de la nave superior (punto 4), el apoyo de la cubierta baja (punto 5), el arranque derecho de la bóveda de la nave lateral (punto $6)$, el apoyo del pilar (punto 7), la parte superior del botarel (punto 8), el arranque del arbotante superior (punto 9), el arranque del arbotante inferior (punto 10), el arranque izquierdo de la bóveda de la nave lateral (punto 11) y el apoyo del botarel (punto 12).

La Figura 4 muestra el mapa de tensiones en la sección transversal de la catedral para el cálculo con la combinación de variables E1D1V1A1. En ella se observa que el valor de las tensiones es muy bajo, obteniéndose valores máximos en torno a $1 \mathrm{MPa}$ en compresión y nulos o despreciables en tracción. column (point 1); the upper buttress support (point 2); the lower buttress support (point 3); the upper nave vault springing (point 4); the lower roof support (point 5); the right springing for the lateral nave vault (point 6); the column support (point 7); the top of the pier (point 8); the upper buttress springing (point 9); the lower buttress springing (point 10); the left springing for the lateral nave vault (point 11); and the pier support (point 12).

Figure 4 maps the stress on the cathedral cross-section calculated for the E1D1V1A1 combination of variables. Note that the stress level is very low, with maximum values on the order of $1 \mathrm{MPa}$ for compression, and nil or negligible for tensile stress. 


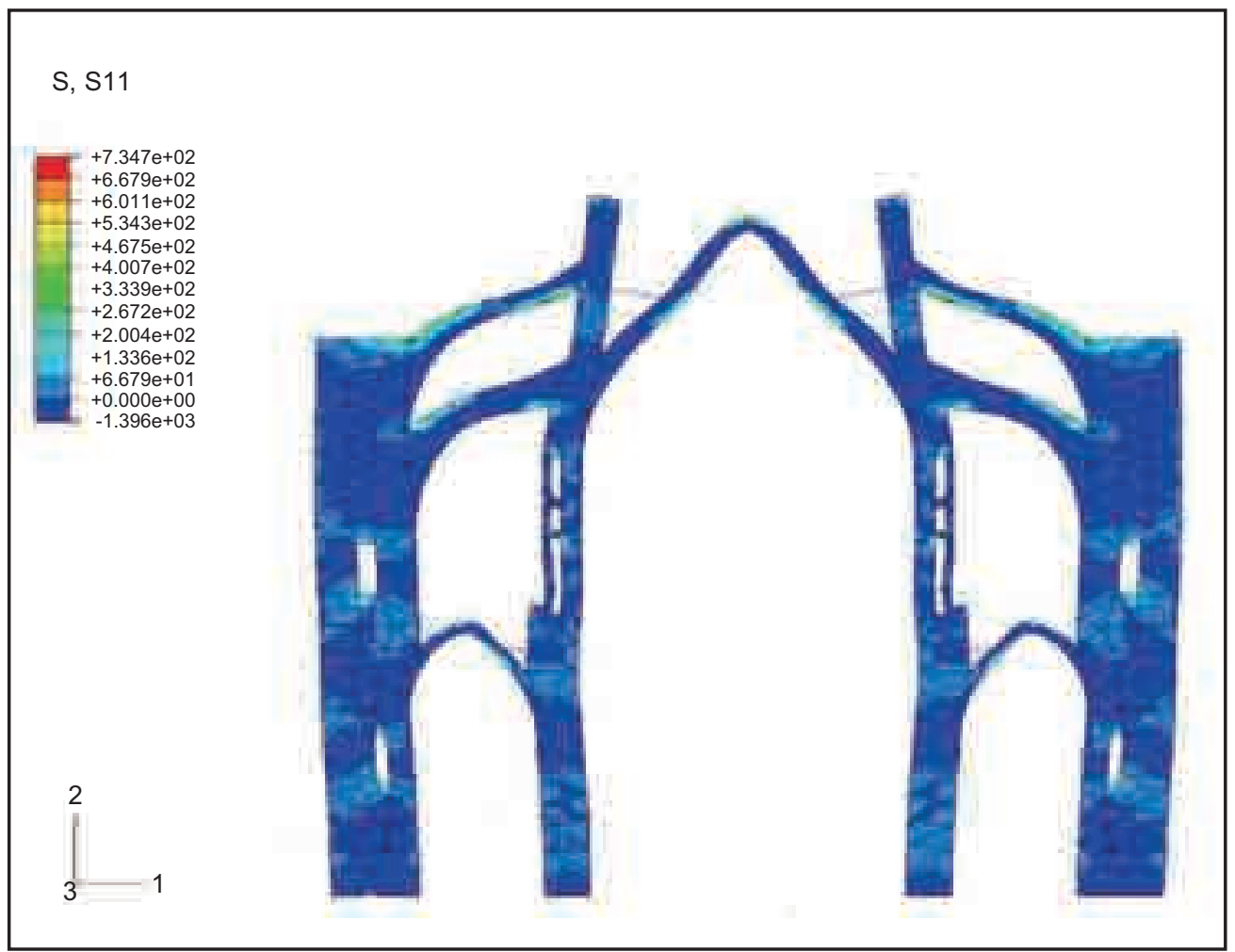

Figura 4. Mapa de tensiones sobre la malla deformada de elementos finitos de la sección transversal de la catedral de León bajo la combinación de variables E1D1V1A1.

Figure 4. Stress distribution mapped on finite element mesh of Leon cathedral cross-section as deformed by the E1D1V1A1 combination of variables.

\section{RESULTADOS DEL ANÁLISIS DE SENSIBILIDAD}

La combinación de las variables independientes presentadas en el apartado anterior proporciona 108 casos, calculados por el método de los elementos finitos para la sección transversal de la catedral. Los resultados obtenidos se han analizado en los puntos de mayor solicitación, mostrados en el apartado anterior (Figura 3). En cada uno de esos puntos se han estudiado cuatro variables resultantes del cálculo:

- Desplazamiento horizontal (U1).

- Desplazamiento vertical (U2).

- Tensión horizontal (S11).

- Tensión vertical (S22).

Con los resultados numéricos de cada cálculo se ha realizado un estudio estadístico de sensibilidad, basado en el análisis de frecuencias (31), que permite identificar qué variables independientes afectan más con su modificación a los resultados de tensiones y desplazamientos en los puntos de estudio, así cómo cuales son las combinaciones más desfavorables. Una descripción detallada del método se encuentra en la referencia (3).

\section{SENSITIVITY ANALYSIS RESULTS}

The combination of independent variables discussed in the preceding section yielded 108 cases, calculated for the cathedral cross-section using the finite element method. The findings were analyzed for the most highly stressed points, shown in Figure 3. Four dependent variables resulting from the calculations were studied in each of those points, namely:

- Horizontal displacement (U1).

- Vertical displacement (U2).

- Horizontal stress (S11).

- Vertical stress (S22).

The numerical results for each calculation were used to conduct a frequency analysis-based statistical study of sensitivity (31) that identified which independent variables had the greatest effect on the stress and displacement results at the points studied, and which combinations were most adverse. A detailed description of the method can be found in reference (3). 
A continuación se presentan los resultados del análisis de sensibilidad. La Tabla 4 muestra la combinación de variables más desfavorable para el desplazamiento horizontal (U1) y vertical (U2) en cada punto de estudio. Análogos resultados presenta la Tabla 5 para la tensión horizontal (S11) y vertical (S22). Dado que hay variables que introducen asimetría en la sección, por ejemplo los asientos de pilares y botareles de un lado, los resultados se presentan de forma independiente para la parte izquierda y derecha de la sección. En todos los casos el símbolo "*" asociado a una variable independiente indica que todos los valores de dicha variable afectan por igual al resultado de la variable dependiente estudiada (desplazamiento o tensión).

\section{Desplazamiento horizontal (U1)}

En la Tabla 4 se observa cómo para la mayoría de los puntos de la parte izquierda de la sección transversal la combinación de variables independientes más desfavorable corresponde a los valores de E3 y V2, es decir:

- Asignación a cada sillar del módulo de deformación que le corresponde, un valor para cada uno de los tres tipos de piedra, con una distribución de tipos de piedra en la fábrica muy próxima a la realmente observada en la catedral (E3).

- Descenso impuesto de $5 \mathrm{~cm}$ en el botarel izquierdo (V2).
The sensitivity analysis results are discussed below. Table 4 shows the most adverse combination of variables for horizontal (U1) and vertical (U2) displacement at each point studied. Analogous findings are given in Table 5 for horizontal (S11) and vertical stress (S22). Since certain variables, such as column and pier settlement on only one side, introduced asymmetry in the section, the results for the left and right sides of the section are shown separately. An "*" alongside an independent variable means that all the values of that variable had the same effect on the dependent variable studied (displacement or stress).

\section{Horizontal displacement (U1)}

As Table 4 shows, for most of the points on the left side of the cross-section, values E3 and V2 constituted the most adverse combination of independent variables, i.e.:

- Assignment of the respective modulus of deformation to each type of ashlar stone, whose distribution in the model was very close to their distribution as actually observed in the cathedral (E3).

- Descent imposed on the left pier, $5 \mathrm{~cm}$ (V2).

Tabla 4 / Table 4

Combinaciones de variables que más influyen en los desplazamientos horizontal y vertical de las zonas de estudio. Combinations of independent variables with the most adverse effect on horizontal and vertical displacements at the points studied.

\begin{tabular}{|c|c|c|}
\hline \multicolumn{3}{|c|}{$\begin{array}{c}\text { Desplazamiento horizontal }(\mathbf{x}) \\
\text { Horizontal displacement ( } x \text { direction) (U1) }\end{array}$} \\
\hline $\begin{array}{l}\text { Punto } \\
\text { Point }\end{array}$ & $\begin{array}{l}\text { Izquierda } \\
\text { Left side }\end{array}$ & $\begin{array}{l}\text { Derecha } \\
\text { Right side }\end{array}$ \\
\hline 1 & E3D*V2A* & E3D*V1A2 \\
\hline 2 & E3D*V2A* & $\begin{array}{l}\text { E3D*V1A2 } \\
\text { E3D*V3A2 }\end{array}$ \\
\hline 3 & E3D*V2A* & $\begin{array}{l}\mathrm{E} 3 \mathrm{D} * \mathrm{~V} 1 \mathrm{~A} 2 \\
\mathrm{E} 3 \mathrm{D} * \mathrm{~V} 3 \mathrm{~A} 2\end{array}$ \\
\hline 4 & $\mathrm{E} 3 \mathrm{D} * \mathrm{~V} 2 \mathrm{~A} *$ & $\begin{array}{l}\mathrm{E} 1 \mathrm{D} * \mathrm{~V} 1 \mathrm{~A} 2 \\
\mathrm{E} 2 \mathrm{D} * \mathrm{~V} 3 \mathrm{~A} 2\end{array}$ \\
\hline 5 & E3D*V2A* & E1D*V1A* \\
\hline 6 & $\mathrm{E} 3 \mathrm{D} * \mathrm{~V} 2 \mathrm{~A} *$ & $\begin{array}{l}E 2 D * V 2 A 2 \\
E 2 D * V 3 A 2\end{array}$ \\
\hline 7 & E2D*V3A* & \\
\hline 8 & E3D*V2A* & E*D*V2A* \\
\hline 9 & E3D*V2A* & $E * D * V 2 A *$ \\
\hline 10 & E3D*V2A* & $\mathrm{E} * \mathrm{D} * \mathrm{~V} 2 \mathrm{~A}^{*}$ \\
\hline 11 & E3D*V2A* & $\mathrm{E}^{*} \mathrm{D} * \mathrm{~V} 2 \mathrm{~A}^{*}$ \\
\hline 12 & E3D*V2A2 & \\
\hline
\end{tabular}

\begin{tabular}{|c|c|c|}
\hline \multicolumn{3}{|c|}{ Desplazamiento vertical (y) } \\
\hline $\begin{array}{c}\text { Punto } \\
\text { Point }\end{array}$ & $\begin{array}{c}\text { Izquierda } \\
\text { Left side }\end{array}$ & $\begin{array}{c}\text { Derecha } \\
\text { Right side }\end{array}$ \\
\hline 1 & E3D*V3A2 & E3D*V*A2 \\
\hline 2 & E3D*V3A2 & E3D*V*A2 \\
\hline 3 & E3D*V3A2 & E3D*V*A2 \\
\hline 4 & E3D*V3A2 & E3D*V*A2 \\
\hline 5 & E3D*V3A2 & E3D*V*A2 \\
\hline 6 & E3D*V3A2 & E3D*V*A2 \\
\hline 7 & E*D*V3A* & \\
\hline 8 & E2D*V2A* & E2D*V2A2 \\
& E1D*V2A* & E2D*V3A2 \\
\hline 9 & E3D*V2A* & E2D*V1A2 \\
\hline 10 & E3D*V2A* & E2D*V1A2 \\
\hline 11 & E3D*V2A* & E*D*V2A* \\
\hline 12 & E*D*V1A2 & \\
\hline & & \\
\hline
\end{tabular}


Por consiguiente, para el desplazamiento horizontal será importante tener en cuenta que la fábrica está compuesta por distintos tipos de piedra con diferentes propiedades mecánicas. Los dos puntos de la sección que se ven afectados por otras variables son los de la cimentación. Para el apoyo del pilar (punto 7) las variables independientes más significativas son E2, que indica valores variables (distribuidos aleatoriamente) del módulo de deformación longitudinal para los sillares de la sección, y V3, variable que impone un descenso de $5 \mathrm{~cm}$ del pilar izquierdo. Para el apoyo del botarel (punto 12) la combinación que más afecta es E3V2, ya comentada, junto con la variable A2 que asigna valores distribuidos aleatoriamente del peso específico. Obviamente, en estos puntos, 7 y 12 , la variable independiente que más afecta al desplazamiento $U 1$ es el desplazamiento vertical impuesto en el propio punto (condición de apoyo).

En el caso de la parte derecha de la sección distinguimos entre el pilar y el botarel. La variable independiente que más condiciona el comportamiento del pilar (puntos 1 a 6) de la parte derecha es A2. Las zonas del pilar sobre las que se apoyan los arbotantes (puntos 1 a 4), la combinación de A2 con el valor E3 del módulo de deformación longitudinal es la que más afecta; estos puntos no se ven afectados por el descenso del botarel izquierdo (V2). El desplazamiento horizontal de la zona del pilar derecho sobre la que arranca la bóveda baja (punto 6) está muy condicionado por la combinación E2A2 con los descensos del botarel (V2) y del pilar (V3) de la parte izquierda de la sección.

El desplazamiento horizontal de los puntos de estudio del botarel derecho (puntos 8 a 12) está fuertemente condicionado por el descenso del botarel izquierdo (V2).

Cabe destacar cómo para ninguno de los puntos de la sección, tanto de la parte izquierda como derecha, es importante la condición de deformación impuesta a los pilares (variable D).

\section{Desplazamiento vertical (U2)}

En la Tabla 4 se observa cómo para el pilar de la parte izquierda de la sección transversal (puntos 1 a 6) la combinación de variables independientes más desfavorable corresponde a los valores E3V3A2, es decir:

- Asignación a cada sillar del módulo de deformación que le corresponde, un valor para cada uno de los tres tipos de piedra, con una distribución de tipos de piedra en la fábrica muy próxima a la real (E3).

- Descenso impuesto de $5 \mathrm{~cm}$ en el pilar izquierdo (V3).

- Distribución aleatoria del peso específico en los sillares de la sección (A2).
Consequently, when determining horizontal displacement, account must be taken of the fact that the masonry consists of different types of stone with different mechanical properties. The two points of the cross-section affected by other variables were the two foundation points. For the column support (point 7) the most significant independent variables were E2, or (randomly distributed) variable values for ashlar longitudinal modulus of deformation, and V3, which imposes a 5-cm descent on the left column. For the pier support (point 12), the combination with the heaviest impact was E3V2, together with $A 2$ or random assignment of specific weight values. Obviously, at points 7 and 12, the independent variable that affected horizontal displacement U1 the most was the vertical displacement imposed on the respective point (support condition).

On the right side of the section, a distinction can be drawn between column and pier. The independent variable that conditioned right side column behaviour (points 1 to 6) most intensely was A2. The areas of the column where the buttresses rest (points 1 to 4) were most heavily impacted by the combination of $A 2$ and longitudinal modulus of deformation E3; these points were not affected by the descent of the left pier (V2). Horizontal displacement in the area of the right column constituting the springing for the lower vault (point 6) was highly conditioned by the combination E2A2 and the descent of the left pier (V2) and left column (V3).

Horizontal displacement at the points on the right pier (8 to 12) was strongly affected by the descent of the left pier (V2).

Note that none of the points studied on either the left or right side of the section was materially affected by the deformation imposed on the columns (variable D).

\section{Vertical displacement (U2)}

As Table 4 shows, for the left-hand column (points 1 to $6)$, the most adverse combination of independent variables was E2V3A2, i.e.

- Assignment of the respective modulus of deformation to each type of ashlar stone, whose distribution in the model was very close to their distribution as actually observed in the cathedral (E3).

- descent imposed on left column, $5 \mathrm{~cm}$ (V3).

- random distribution of specific weight in the ashlars (A2). 
En el botarel de la parte izquierda (puntos 8 a 11) la combinación más desfavorable corresponde también al módulo E3, pero con la condición de vinculación V2 (descenso impuesto en el botarel).

En el caso de la parte derecha de la sección distinguimos entre el pilar y el botarel. La combinación de variables independientes que más condiciona el comportamiento del pilar (puntos 1 a 6) de la parte derecha es E3A2, y la del botarel (puntos 8 a 11) E2A2.

En este caso, al igual que ocurría con el desplazamiento horizontal, para ninguno de los puntos de la sección, tanto de la parte izquierda como derecha, es importante la condición de deformación impuesta a los pilares (variable D).

\section{Tensiones en dirección horizontal (S11)}

En la Tabla 5 se observa cómo para la mayoría de los puntos de la parte izquierda de la sección transversal la combinación de variables independientes más desfavorable corresponde a los descensos del botarel (V2) y del pilar (V3), combinados con un valor uniforme del módulo de deformación longitudinal (E1) para toda la sección y un valor de dicho módulo distribuido aleatoriamente (E2).

Al único punto al que le afecta la variable E3, asignación a cada sillar de su módulo de deformación, es la esquina superior exterior del botarel (punto 8), donde la combinación más desfavorable de los parámetros es E3D3V3A2. No obstante, esto carece de importancia porque las tensiones en esa zona son muy bajas (no así los desplazamientos) en comparación con otras zonas del pilar y los botareles.

Para todos los puntos analizados en la parte izquierda de la sección no parece influir la modificación de las acciones (variable independiente $A$ ).

En el caso de la parte derecha de la sección los descensos del botarel (V2) y del pilar (V3) de la parte izquierda de la sección influyen de forma directa en las tensiones del pilar y botarel del lado derecho. En la parte superior del pilar (punto 1), el arranque derecho de la bóveda de la nave lateral (punto 6) y el apoyo del botarel (punto 12), la combinación más desfavorable de variables es E2A2. Para el apoyo de la bóveda baja (punto 5) y el apoyo del pilar (punto 7) lo es la combinación E3A2.

Para ninguna de las dos partes de la sección parece importante la deformación impuesta a los pilares (D), con la excepción de algún punto muy localizado (punto 8) sometido a tensiones muy bajas.
For the left pier (points 8 to 11) the most adverse combination also involved modulus E3, but here in conjunction with support condition V2 (descent imposed on pier).

In the right side of the section, a distinction can be drawn between column and pier. The combination of independent variables that had the greatest effect on right side column behaviour (points 1 to 6) was E3A2, while the pier (points 8 to 11) was most heavily impacted by E2A2.

Note that, as in the case of horizontal displacement, none of the points studied on either the left or right side of the section was materially affected by the deformation imposed on the columns (variable D).

\section{Horizontal stress (S11)}

As Table 5 shows, for most of the points on the left side of the cross-section, the most adverse combination of independent variables involved pier (V2) and column (V3) descent, combined with either a uniform (E1) or a randomly distributed (E2) longitudinal modulus of deformation.

The sole point affected by variable E3, attribution to each ashlar of its modulus of deformation, was the top outside corner of the pier (point 8), where the most adverse combination of parameters was E3D3V3A2. This is unimportant, however, because stress (but not displacement) was very low in this area compared to other column and pier areas.

Varying the value of the actions (independent variable A) did not appear to affect any of the left side points analyzed.

Left pier (V2) and column (V3) descent had a direct effect on the stress affecting the right column and pier. The most adverse combination of variables for the top of the column (point 1), the right springline of the lateral nave vault (point 6) and the pier support (point 12), was E2A2. For the lower vault support (point 5) and the column support (point 7), the worst combination was E3A2.

None of the points in the cross-section appeared to be significantly affected by the deformation imposed on the column (D), with the exception of one localized area (point 8) subjected to very low stress. 
Tabla 5 / Table 5

Combinaciones de variables que más influyen en la tensión horizontal y vertical de las zonas de estudio. Combinations of independent variables with the most adverse effect on horizontal and vertical stress at the points studied.

\begin{tabular}{|c|c|c|}
\hline \multicolumn{3}{|c|}{$\begin{array}{l}\text { Tensión en dirección horizontal (x) } \\
\text { Horizontal stress ( } x \text { direction) (S11) }\end{array}$} \\
\hline $\begin{array}{l}\text { Punto } \\
\text { Point }\end{array}$ & $\begin{array}{l}\text { Izquierda } \\
\text { Left side }\end{array}$ & $\begin{array}{l}\text { Derecha } \\
\text { Right side }\end{array}$ \\
\hline 1 & $E 2 D * V * A 2$ & $E 2 D * V * A 2$ \\
\hline 2 & $\begin{array}{l}\text { E1D*V2A* } \\
\text { E2D*V2A* } \\
\text { E1D*V3A* } \\
\text { E2D*V3A* }\end{array}$ & E1D*V2A* \\
\hline 3 & $\begin{array}{l}\text { E1D*V2A* } \\
\text { E2D*V2A* } \\
\text { E1D*V3A* } \\
\text { E2D*V3A* }\end{array}$ & $\begin{array}{l}\mathrm{E} 1 \mathrm{D} * \mathrm{~V} 2 \mathrm{~A}^{*} \\
\mathrm{E} 1 \mathrm{D} * \mathrm{~V} 3 \mathrm{~A}^{*}\end{array}$ \\
\hline 4 & $\begin{array}{l}\text { E1D*V2A* } \\
\text { E2D*V2A* } \\
\text { E1D*V3A* } \\
\text { E2D*V3A* }\end{array}$ & $\begin{array}{l}\text { E1D*V2A* } \\
\text { E2D*V2A* } \\
\text { E1D*V3A* } \\
\text { E2D*V3A* }\end{array}$ \\
\hline 5 & E1D*V3A* & E3D*V*A2 \\
\hline 6 & $\begin{array}{l}\mathrm{E} 1 \mathrm{D} * \mathrm{~V} 3 A^{*} \\
\mathrm{E} 2 \mathrm{D} * \mathrm{~V} * \mathrm{~A} 2\end{array}$ & E2D*V3A* \\
\hline 7 & E2D*V3A* & E3D*A2V* \\
\hline 8 & $\begin{array}{l}\text { E1D*V2A* } \\
\text { E3D3V3A2 }\end{array}$ & $\begin{array}{l}\text { Dispersión } \\
\text { Scatter }\end{array}$ \\
\hline 9 & $\begin{array}{l}\text { E1D*V2A* } \\
\text { E2D*V2A* } \\
\text { E1D*V3A* } \\
\text { E2D*V3A* }\end{array}$ & $\begin{array}{l}\mathrm{E} 1 \mathrm{D} * \mathrm{~V} 2 \mathrm{~A}^{*} \\
\mathrm{E} 2 \mathrm{D} * \mathrm{~V} 1 \mathrm{~A}^{*}\end{array}$ \\
\hline 10 & $\begin{array}{l}\text { E1D*V2A } \\
\text { E2D*V2A* }\end{array}$ & $\begin{array}{l}\mathrm{E} 1 \mathrm{~A}^{*} \mathrm{~V} 2 \mathrm{~A}^{*} \\
\mathrm{E} 1 \mathrm{D} * \mathrm{~V} 3 \mathrm{~A}^{*}\end{array}$ \\
\hline 11 & E2D*V3A* & $\mathrm{E}^{*} \mathrm{D} * \mathrm{~V} 2 \mathrm{~A}^{*}$ \\
\hline 12 & $\begin{array}{l}\text { E1D*V2A* } \\
\text { E2D*V2A* } \\
\text { E2D*V3A* }\end{array}$ & $\mathrm{E} 2 \mathrm{D} * \mathrm{~A} 2 \mathrm{~V} *$ \\
\hline
\end{tabular}

\begin{tabular}{|c|c|c|}
\hline \multicolumn{3}{|c|}{$\begin{array}{l}\text { Tensión en dirección vertical }(y) \\
\text { Vertical stress ( } y \text { direction) (S22) }\end{array}$} \\
\hline $\begin{array}{l}\text { Punto } \\
\text { Point }\end{array}$ & $\begin{array}{l}\text { Izquierda } \\
\text { Left side }\end{array}$ & $\begin{array}{l}\text { Derecha } \\
\text { Right side }\end{array}$ \\
\hline 1 & $E 2 D * V * A 2$ & $E * D * V * A 2$ \\
\hline 2 & $\begin{array}{l}\text { E2D*V2A* } \\
\text { E1D*V3A* } \\
\text { E2D*V3A* }\end{array}$ & $\begin{array}{l}\mathrm{E} 1 \mathrm{D} * \mathrm{~V} 2 \mathrm{~A}^{*} \\
\mathrm{E} 2 \mathrm{D} * \mathrm{~V} 1 \mathrm{~A} 2\end{array}$ \\
\hline 3 & $\begin{array}{l}\text { E1D*V2A* } \\
\text { E2D*V2A* } \\
\text { E1D*V3A* } \\
\text { E2D*V3A* }\end{array}$ & $\begin{array}{l}\mathrm{E} 1 \mathrm{D} * \mathrm{~V} 2 \mathrm{~A} 1 \\
\mathrm{E} 1 \mathrm{D} * \mathrm{~V} 2 \mathrm{~A} 3\end{array}$ \\
\hline 4 & $\begin{array}{l}\text { E1D*V2A* } \\
\text { E2D*V2A* } \\
\text { E1D*V3A* } \\
\text { E2D*V3A* }\end{array}$ & $\begin{array}{l}\text { Dispersión } \\
\text { Scatter }\end{array}$ \\
\hline 5 & E1D*V3A* & $E 3 D * V * A 2$ \\
\hline 6 & E1D*V3A* & $E 2 D * V * A 2$ \\
\hline 7 & $\begin{array}{l}\text { E1D*V2A* } \\
\text { E2D*V2A* } \\
\text { E1D*V3A* } \\
\text { E2D*V3A* }\end{array}$ & $\begin{array}{l}E 1 D * V 2 A 2 \\
E 1 D * V 3 A 2\end{array}$ \\
\hline 8 & E3D3V3A2 & E3D3V3A2 \\
\hline 9 & $\begin{array}{l}E 1 D * V 2 A * \\
E * V 3 D * A 2\end{array}$ & $E * V 2 D * A 2$ \\
\hline 10 & E1D*V2A* & $\begin{array}{l}\mathrm{E} 1 \mathrm{~A}^{*} \mathrm{~V} 2 \mathrm{~A} 3 \\
\mathrm{E} 1 \mathrm{D} * \mathrm{~V} 2 \mathrm{~A} 2\end{array}$ \\
\hline 11 & $\begin{array}{l}\text { E1D*V2A* } \\
\text { E2D*V2A* }\end{array}$ & $\begin{array}{l}E 1 D * V 1 A 2 \\
E 2 D * V 1 A 2\end{array}$ \\
\hline 12 & $\begin{array}{l}\text { E1D*V2A* } \\
\text { E3D*V1A2 }\end{array}$ & $\mathrm{E} 1 \mathrm{D} * \mathrm{~V} 1 \mathrm{~A} 2$ \\
\hline
\end{tabular}

\section{Tensiones en dirección vertical (S22)}

En la parte izquierda de la sección transversal la variable independiente que más afecta a la tensión en la dirección vertical es el descenso del pilar (V3) y el descenso del botarel (V2). Este resultado es lógico porque los asientos inducen aumento de tensiones en una estructura hiperestática. Estos parámetros en combinación con E1 y E2 afectan a las zonas altas del pilar, no así el valor E3 en el que se ha considerado el módulo real para cada tipo de piedra.

En la parte izquierda de la sección transversal no afecta de forma importante la variación en las acciones consideradas $(A)$ ni las deformaciones impuestas a los pilares (D), con la excepción el del punto 8, correspondiente a la esquina exterior del botarel, donde la combinación

\section{Vertical stress (S22)}

The independent variables affecting vertical stress on the left side of the cross-section were column (V3) and pier (V2) descent. This finding makes good sense, for settling raises stress in statically indeterminate structures. These parameters affected the top of the column when combined with E1 and E2, but not with value E3, where each type of stone was assigned its actual modulus.

Neither variations in the actions considered $(A)$ nor in the deformations imposed on columns (D) had any effect on the left side of the cross-section, except at point 8, located on the outer corner of the pier, for which E3D3V3A2 was the most adverse combination. 
E3D3V3A2 es la más desfavorable. No obstante, esto carece de importancia, al igual que con $S 11$, porque las tensiones en esa zona son muy bajas (no así los desplazamientos) en comparación con otras zonas del pilar y los botareles.

La parte derecha de la sección muestra mayor dispersión en los resultados, no pudiendo establecer resultados globales de los parámetros independientes, por tanto para este caso habrá que estudiar con más detalle cada uno de los puntos de la sección. La única excepción sería la influencia global de la acción A2, que por incluir zonas con peso específico muy alto (para simular la presencia de rellenos) provoca tensiones verticales mayores en algunos puntos.

\section{DISCUSIÓN DE LOS RESULTADOS}

El cálculo estructural de la sección transversal de la catedral muestra que el nivel de tensiones de compresión en la sección transversal es bajo, muy inferior a la resistencia de la fábrica, y en particular de la piedra (véase Tabla 1). Obteniéndose valores máximos en torno a 1,6 MPa. Por ello, de los posibles problemas de seguridad estructural, parecen descartados aquellos relacionados con exceso de tensiones, salvo que hubiese un importante deterioro del material, lo que no se ha apreciado y no parece probable. Esto lleva a centrar la atención en los posibles problemas relacionados con movimientos excesivos de algunos elementos de la sección transversal, como son el arranque de la bóveda de la nave principal, de los arbotantes, o de la nave lateral.

No es objeto de este trabajo analizar los posibles mecanismos de fallo de la estructura. Sin embargo, autores como Heyman (32) han destacado la importancia y gravedad de los posibles movimientos en la estructura de un edifico gótico, pues la pérdida de forma de la estructura, con un mortero muy deteriorado o casi desaparecido, no tiene capacidad de movilizar tensiones de tracción pudiéndose producir el colapso por la formación de rótulas suficientes dando lugar a un mecanismo. Este proceso se puede generar por la aparición de asientos diferenciales o el fallo de los apoyos y/o empotramientos de los arcos.

De los resultados obtenidos en el apartado anterior se destaca la importancia que tiene evaluar correctamente el módulo de deformación de la fábrica, con la distribución real de sillares de piedra con origen distinto (Hontoria, Boñar o País), en los movimientos de la estructura bajo las acciones estudiadas, especialmente frente a los posibles asientos diferenciales del pilar y del botarel. La incorrecta evaluación de la deformabilidad de la estructura puede sobrevalorar o minusvalorar los desplazamientos de la
This finding was of little relevance, however, for as in S11, stress (but not displacement) was very low in this area compared to other column and pier areas.

The findings for the right side were too disperse to establish overall results for the independent parameters. In this case, each of the points defined would have to be studied in greater detail. The sole exception would be the global effect of action A2, since it included areas with high specific weight values (to simulate the presence of fill), generating greater vertical stress on some of the points studied.

\section{DISCUSSION OF RESULTS}

Structural engineering of the cross-section of the cathedral showed that the level of compressive stress was much lower than both masonry strength and especially stone strength (see Table 1). The maximum values found were on the order of $1.6 \mathrm{MPa}$. Hence, excess stress would appear to be ruled out as the cause of possible structural safety problems, barring severe material decay, which was neither detected nor seems likely. Attention, then, should focus on possible problems associated with undue movement in some of the elements in the cross-section, such as the springings for the main and lateral nave vaults and the buttresses.

Analysis of the possible mechanisms of structural failure falls outside the scope of the present study. Authors such as Heyman (32), however, stressed the importance and severe consequences of possible movement in Gothic structures. The combination of deformation and highly deteriorated or nearly non-existent mortar prevents such buildings from mobilizing tensile stresses, which may lead to collapse if sufficient hinges form. This process may be triggered by differential settling or failure of arch supports and/or springing lines.

The results set out in the preceding section reveal the importance of correctly assessing the masonry modulus of deformation for determining structural movement induced by the actions studied, especially possible differential settling in columns and piers. In such assessments, the different types of ashlar stones (Hontoria, Boñar, País) should be distributed in the model as they are in the actual structure. An incorrect assessment of structural deformability may over- or 
estructura y, como el colapso previsible es por pérdida de forma, conducir a estimaciones de la seguridad erróneas.

Los modelos empleados para el cálculo mediante elementos finitos son modelos continuos, que no contemplan la posibilidad de apertura de juntas entre sillares. Estos modelos pueden resultar excesivamente rígidos al evaluar las tensiones generadas por los asientos diferenciales, por lo que los valores de las tensiones obtenidos del cálculo deben tratarse con prudencia y ser empleados como una tendencia. No obstante, los valores de las tensiones obtenidos son bajos en relación a la resistencia de la fábrica.

Con objeto de ver la importancia de puede tener el analizar la estructura con un método de cálculo más sofisticado, que contempla las juntas entre bloques y su posible apertura, se remite al lector a las referencias (3) y (33), en las que se recoge el estudio detallado de un arbotante de la catedral de León comparando la posibilidad de apertura de juntas (modelo de elementos finitos con elementos junta entre sillares) con un modelo continuo sin juntas (como el aquí empleado). El resultado obtenido muestra que en las zonas de tracción hay una ligera apertura de las juntas (el material no resiste tracciones en la junta) de forma que la línea de presiones queda en el interior de la sección a lo largo de toda la directriz, desapareciendo las pequeñas tracciones que aparecen en el modelo sin juntas. Sin embargo, apenas hay modificaciones en las tensiones de compresión ni en la deformada del arbotante. Por esta razón aquí se ha presentado un modelo continuo, sin juntas, que simplifica mucho el cálculo, a la vez que se ha comprobado que las tracciones que generan los asientos diferenciales son prácticamente despreciables. Este aspecto confirma lo adecuada que es la forma estructural a las propiedades del material, de modo que todo él está sometido a compresión y no a tracción.

La baja influencia de las acciones del viento y la temperatura se justifica porque la sección de los elementos estructurales de la sección transversal, especialmente de los pilares y el botarel, es muy grande, preponderando la acción del peso propio sobre las otras acciones. En las referencias (3) y (33) se muestra cómo en los arbotantes encargados de transmitir el empuje del viento de la cubierta al botarel la acción del viento sí es importante.

El desplazamiento horizontal de la directriz de los pilares en la zona de apoyo de la bóveda baja (desplazamiento hacia el interior) y de la bóveda alta (desplazamiento hacia fuera) que puede alarmar en una inspección visual apenas tiene importancia en la evaluación de la seguridad. Este desplazamiento, como ya se ha comentado, responde al proceso constructivo, probablemente underestimate displacement and, inasmuch as collapse predictions are based on deformation, lead to erroneous safety estimates.

Finite element calculations are performed with continuous models that make no provision for possible gaps in inter-block joints. Since such models may prove to be too rigid to assess stress generated by differential settling, the stress values obtained should be viewed as trends only and used with caution. Be it said, however, that the stress values obtained are low compared to masonry strength.

The reader is referred to (3) and (33) for a discussion of the possible importance of analyzing structures with more sophisticated methods that take account of interblock joints and their possible opening. Those papers report the findings of a detailed study on a Leon cathedral buttress obtained by comparing possible joint opening (finite element model with inter-block joints) to a continuous model (such as used here). The results showed a slight opening of joints in the tensile areas (the material does not resist tensile stress in joints), such that the pressure line remained within the cross-section throughout, while the minor tensile stresses appearing in the model without joints disappeared. Nonetheless, the compressive stress on the buttress and the shape of its deformation were barely affected. Consequently, since the tensile stress generated by differential settling was found to be practically negligible, a continuous, jointless model was used here to simplify calculations. The foregoing confirmed the suitability of the structural form to material properties, so that the whole is subjected to compressive rather than tensile stress.

The explanation for the scant impact of wind and temperature lies in the large scale of the structural members involved, particularly columns and piers, whose self weight prevails over other actions. By contrast, references (3) and (33) showed that wind action is relevant in the buttresses, which transfer wind thrust from the roof to the pier.

The horizontal displacement of columns in the areas where the lower vault (inward deviation) and upper vault (outward deviation) rest, which may be cause for concern in a visual inspection, is scantly relevant for safety assessments. Such deviations, as noted earlier, are a result of the construction process, although probably accentuated by deferred deformation. The 
incrementado por las deformaciones diferidas. La razón de la baja influencia de esta variable está en que la sección del pilar es muy amplia, el esfuerzo vertical es de compresión y la excentricidad pequeña, por lo que la resultante queda dentro del núcleo central de la sección.

\section{CONCLUSIONES Y COMENTARIOS FINALES}

Los resultados obtenidos han puesto de manifiesto que la evaluación de las propiedades mecánicas de los materiales que constituyen la fábrica de la catedral de León es primordial para evaluar su seguridad y posible evolución bajo acciones no buscadas (por ejemplo, asientos inducidos por obras cercanas) o actuaciones de reparación y conservación. Dado el bajo nivel tensional de las estructuras de fábrica es preponderante conocer la deformabilidad frente a la resistencia o la densidad, salvo que hubiese un alto deterioro de la piedra, que no es el caso. El módulo de deformación de la fábrica es imprescindible para estimar adecuadamente los movimientos de la estructura, y, por tanto, la posible pérdida de forma de la estructura y posterior colapso.

La forma estructural se adapta muy bien a las características mecánicas de la fábrica, no apreciándose tracciones en la sección transversal bajo las condiciones de carga habituales. Las acciones externas más desfavorables son los asientos diferenciales, que inducen movimientos relativos y la aparición de zonas con tracciones moderadas. Sin embargo, como la fábrica está constituida por sillares con juntas entre ellos que se pueden abrir y permiten pequeñas rotaciones entre sillares, se adapta bien a estos posibles asientos, siempre que su magnitud sea moderada.

Desde el punto de vista del cálculo estructural, conviene tener un conocimiento preciso de los rellenos de bóvedas y pilares, especialmente volumen y densidad, ya que la acción del peso propio es preponderante frente a otras acciones variables como el empuje del viento o las variaciones térmicas.

En términos generales, el nivel tensional de la sección transversal de la catedral de León es bajo, la conservación es buena y la seguridad adecuada, incluso bajo el peor escenario de propiedades mecánicas del material que constituye la fábrica.

\section{AGRADECIMIENTOS}

Los autores agradecen al Ministerio de Educación y Ciencia la ayuda económica concedida a través del proyecto BIA2008-03523. Asimismo agradecen a la Junta de Comunidades de Castilla-La Mancha la ayuda concedida a través del proyecto PAI06-0071-9403. large column section, small scale of the eccentricity and compressive nature of the vertical stress explain the scant impact of this variable and the position of the resultant within the central core of the section.

\section{CONCLUSIONS AND FINAL REMARKS}

The findings show that assessing the mechanical properties of the constituent materials in Leon Cathedral masonry is instrumental to determining building safety and possible reaction to unprogrammed actions (such as settling induced by nearby works) or repair and conservation interventions. Given the low stress level in masonry structures, an understanding of deformability is of greater relevance than ascertaining strength or density, except where the stone is severely decayed, which is not the case here. The modulus of deformation value for the masonry is indispensable to correctly estimate structural movements and therefore possible structural deformation and subsequent collapse.

The structural is well adapted to the mechanical characteristics of the masonry, inasmuch as the crosssection is not subjected to tensile stress under normal loading. The most adverse external action is differential settling, which induces relative movements that expose certain areas to moderate tensile stress. Nonetheless, since the masonry consists in ashlars separated by joints that may open to allow minor rotation between stones, it adapts readily to moderate settlement.

Accurate information on fill in vaults and columns, particularly volume and density, is highly relevant to structural engineering, for in buildings of this nature self weight prevails over actions such as wind thrust or variations in temperature.

Generally speaking, the stress level on the cross-section of Leon Cathedral is low and the building is in good condition and satisfactorily safe, even under the worst case scenario for the mechanical properties of the material comprising its masonry.

\section{ACKNOWLEDGEMENTS}

Funding for this research was provided by the Ministry of Education and Science under project BIA2008-03523 and the Regional Government of Castilla-La Mancha under project PAI06-0071-9403. 


\section{BIBLIOGRAFÍA / BIBLIOGRAPHY}

(1) Lourenço, P. B.; Krakowiak, K. J.; Fernandes, F. M. y Ramos, L. F.: "Failure analysis of Monastery of Jerónimos, Lisbon: How to learn from sophisticated numerical models", Engineering Failure Analysis, 14 (2007), pp. 280-300.

(2) Roca, P. y Lodos, J. C.: "Análisis estructural de construcciones históricas", Revista de Obras Públicas, 2 (56) (2001), pp. 38-49.

(3) Casati, M. J.: Influencia del comportamiento de la fábrica en la sensibilidad estructural de las catedrales góticas. Aplicación del estudio a la catedral de León, Tesis Doctoral, Universidad de Castilla-La Mancha (2005).

(4) Casinello, M. J.: "Influencia del espesor de la junta de mortero en la deformabilidad de las fábricas pétreas medievales", Mater. Construcc., vol. 56, 284 (2006), pp. 69-80.

(5) Lourenço, P. B.: "Experimental and numerical issues in the modelling of the mechanical behaviour of masonry", Structural Analysis of Historical Constructions, Barcelona, CIMNE (1998), pp. 57-91.

(6) Rots, J. G. (ed.): Structural Masonry: An Experimental/Numerical Basis For Practical Design Rules, Rotterdam, AA Balkema (1997).

(7) Lourenço, P. B.: "Computations of historical masonry constructions", Prog. Strct. Eng. Mat., vol. 4 (3) (2002), pp. 301-309.

(8) ICOMOS: "Principios para el Análisis, Conservación y Restauración de las Estructuras del Patrimonio Arquitectónico", www.esicomos.org (2001).

(9) De los Ríos, D.: La Catedral de León, vols. I y II, Madrid (1895).

(10) Marcos Fierro, R.: Tratamientos de Conservación Aplicados a Rocas Carbonatadas: Catedral de León, Tesis Doctoral, Universidad de Oviedo (1991).

(11) ASTM Standard C 144-04: Standard Specification for Aggregate for Masonry Mortar, ASTM International, West Conshohocken, PA, www.astm.org (2008).

(12) ASTM Standard C 67-07a: Standard Test Methods for Sampling and Testing Brick and Structural Clay Tile, ASTM International, West Conshohocken, PA, www.astm.org (2008).

(13) ASTM Standard C 1196-04: Standard Test Method for in situ Compressive Stress within Solid Unit Masonry Estimated Using Flatjack Measurements, ASTM International, West Conshohocken, PA, www.astm.org (2008).

(14) ASTM Standard C 1197-04: Standard Test Method for in situ Measurement of Masonry Deformability Properties Using Flat-jack Method, ASTM International, West Conshohocken, PA, www.astm.org (2008).

(15) ASTM Standard E 518-03: Test Method for Flexural Bond Strength of Masonry, ASTM International, West Conshohocken, PA, www.astm.org (2008).

(16) Eurocódigo 6: Proyecto de estructuras de fábrica (albañilería): EN 1996-1-1, Reglas Comunes para Estructuras de Fábrica y Fábrica Armada (2003).

(17) American Concrete Institute (ACI), 530/530.1-08: Building Code Requirements and Specification for Masonry Structures and Related Commentaries (2008).

(18) RILEM TC-127-MS: Committee Materials and Structures, Tests for Masonry Structures, Materials and Structures, vol. 27 (1996).

(19) FL-90: Muros Resistentes de Fábrica de Ladrillo, Norma Básica de la Edificación, Ministerio de Obras Públicas y Transportes (1990).

(20) p.i.e.t. 70: Obras de fábrica, Prescripciones del Instituto Eduardo Torroja, Madrid (1971).

(21) UNE-EN 772-1:2002: Métodos de Ensayo de Piezas para Fábrica de Albañilería, Parte 1: Determinación de la resistencia a Compresión, Asociación Española de Certificación y Normalización, AENOR, Madrid (2008).

(22) Huerta Fernández, S.: Tesis Doctoral, Diseño Estructural de Arcos, Bóvedas y Cúpulas en España ca.1500-ca.1800, Madrid (1990).

(23) Rolando, A.: "Resistencia característica a compresión de una fábrica de ladrillo en función de la resistencia de sus componentes. Comprobación experimental de expresiones analíticas de normativa europea", Mater. Construcc., vol. 56, 283 (2006), pp. 91-98.

(24) Ohler, A.: Zur Berechnung der Druckfestigei von Mauerwerk unter Beruksichtigung der mehrachsigen Spannungszustande in Stein und Mörtel, Bautechnik, 5 (1986).

(25) CIB: International Recommendations for Masonry Structures, Report-Publication 58, International Council for Building.

(26) DIN 18554-1 85-12: Prüfung von Mauerwerk; Ermittlung der Druckfestig- keit und des Elastizitätsmoduls, Deutsches Institut für Normung standards.

(27) Code UIC 778-3 : Recommandations pour l'Evaluation de la Capacité Portante des Ponts-Voùtes Existants en Maçonnerie et Béton, Union Internationales des Chemins de Fer, París (1995).

(28) I.A.B.S.E.: Investigations on the Masonry of the Leaning Tower of Pisa, Symposium: Structural Preservation of the Architectural Heritage, Roma, Italia (1993).

(29) Pieper, K.: Sicherung Historischer Bauteb, Ernst \& Sohn, Berlín (1983).

(30) Ministerio de Vivienda: Código Técnico de la Edificación, Documento Básico SE-AE Acciones en la Edificación, Anejo D (2006).

(31) Castillo, E. y Pruneda, E.: Estadística Aplicada, Ed. Moralea, Santander (2001).

(32) Heyman, J.: Teoría, Historia y Restauración de Estructuras de Fábrica, Instituto Juan de Herrera, Madrid (1995).

(33) Casati, M. J.; Gálvez, J. C. y León, J.: "Análisis estructural de un arbotante de la catedral de León", Reunión de Usuarios de ABAQUS, PRINCIPIA-EQE, S.A. (1996), p. 17. 